\title{
El álbum ilustrado en Nicaragua ${ }^{1}$
}

\author{
María Lourdes Mayorga Mendoza"
}

Recibido: junio de 2016 / Aceptado: agosto de 2016

Las publicaciones nicaragüenses dirigidas al público infantil han sido poco estudiadas por la crítica literaria. En las dos últimas décadas la literatura infantil nicaragüense ha tenido un crecimiento visible, aunque, a diferencia de lo que ocurre en otros países, el álbum ilustrado se ha introducido de manera tímida en la producción nacional. Algunas publicaciones, sin llegar a ser álbumes en la definición del término, destacan por el diálogo que se establece entre texto e imágenes. En este trabajo se analizan libros ilustrados publicados desde 1993 (fecha en que se crea la asociación "Libros para niños") con el fin de identificar algunas características que los aproximarían a los álbumes. El contexto nacional y el futuro del álbum ilustrado, desde las voces de escritores, ilustradores y principales promotores de lectura que apuestan por este tipo de libros en Nicaragua, sirve para contextualizar el análisis.

Palabras clave: literatura infantil nicaragüense / álbum ilustrado

\section{Introducción}

El álbum ilustrado es un formato incipiente en la literatura infantil nicaragüense, sin embargo hay publicaciones que reúnen algunas de sus características más representativas.

El objetivo de este artículo es enumerar las publicaciones nicaragüenses que apuntan a esta naturaleza de creación (tanto visual como escrita), a través del contexto particular de Nicaragua y sus antecedentes. Para esto, las definiciones de Sophie Van der Linden y Uri Schulevitz, resultan ser las más útiles:

Este trabajo fue realizado como trabajo final del Máster en Libros y Literatura Infantil y Juvenil organizado por la Universitat Autònoma de Barcelona y el Banco del Libro de Venezuela.

Universitat Autònoma de Barcelona. Licenciada en Comunicación Social por la Universidad Centroamericana (UCA). En el 2012 gana la séptima edición del concurso nacional 'La Cabra Antonia' de literatura infantil, impulsado por el fondo editorial ¡Libros para Niños!. Correo electrónico: lula.mayorga@gmail.com 
"En un verdadero libro-álbum, las palabras no pueden existir independientemente. Sin las ilustraciones el significado no quedaría claro. Éstas proporcionan la información que no dan las palabras. (...) tanto las palabras como las imágenes son leídas. (...) no sería posible leerle a los niños un álbum a través de la radio porque no sería comprendido”. (Schulevitz, 1980, pp. 131-132, citado por Bosch, 2007, p. 25)

"El álbum sería una forma de expresión que presenta una interacción entre textos (que pueden ser subyacentes) e imágenes (especialmente preponderantes) en el seno de un soporte libro, caracterizado por su libre organización de la doble página, la diversidad de sus realizaciones materiales y la sucesión fluida y coherente de sus páginas". (Van der Linden, 2006, citado por Bosch, 2007, p. 25).

Estas definiciones nos permiten perfilar las características del álbum ilustrado y diferenciarlo del libro ilustrado, en donde el texto lleva la mayor responsabilidad narrativa y la imagen se presenta en contadas ocasiones. Este último formato es el más utilizado en la producción infantil nicaragüense.

A través de entrevistas a profundidad a editores, ilustradores y escritores involucrados, se describirá el panorama del álbum ilustrado y su futuro en Nicaragua. La importancia de este análisis radica en valorar las implicaciones del álbum ilustrado en la formación de lectores críticos y las posibilidades de intercambio que propone entre lectores adultos y niños desde el papel de co-autores de la obra.

\section{Sobre el álbum ilustrado en el contexto nicaragüense}

En Nicaragua el costo de la canasta básica asciende a C $\$ 12,383^{2}$ (doce mil trescientos ochenta y tres córdobas) mensuales, y el salario mínimo apenas cubre el 20\% de la misma. Es así como los libros son un lujo, en particular los álbumes ilustrados, que comúnmente son de grandes dimensiones y de pasta dura.

En Nicaragua las publicaciones tienden a tener un presupuesto modesto. Los libros infantiles nacionales con pasta dura como 'Un güegüe me contó'3 de María López Vigil, 'El caballito de palo'4 de Mario Montenegro y 'Donde nacen las sirenas' ${ }^{5}$ de Alberto Pocasangre', o bien 'Alas nuevas'7 o 'La tribu guanama'8 de Pierre Pierson, se pueden considerar excepciones.

2 Dato oficial del Instituto Nacional de Información de Desarrollo (INIDE) divulgado por el portal digital del Ministerio del Trabajo en Nicaragua: www.mitrab.gob.ni (noviembre, 2014).

3 Se trata de una edición impresa de forma cooperativa en los talleres gráficos de TryckopComunidad (junio de 1989, Suecia). Esta obra fue ganadora del Concurso Nacional 'Los niños queremos cuentos' (Nicaragua, 1988), Wiwilí- ANLIJ (Asociación Nicaragüense de Literatura Infantil y Juvenil).

4 Es la séptima reimpresión a la que se hace alusión: (septiembre, 2013). Impresión Comercial La Prensa. Fondo Editorial Libros para Niños.

5 También del Fondo Editorial Libros para Niños, año 2014. Es la obra ganadora del Primer Concurso Centroamericano de Literatura Infantil.

6 Alberto Pocasangre (1972). Escritor salvadoreño, ganador de la primera edición del Concurso Centroamericano de Literatura Infantil.

7 De la Editorial Mar Dulce, (2011).

8 Contiene dos cuentos: La tribu Guanama y El alma del invierno. Publicado por la Editorial Hispamer (2008). 
Gran parte de los autores que se han interesado en escribir literatura infantil en Nicaragua se han enfocado en crear obras dirigidas a niñas y niños entre los 8 o 10 años de edad, un grupo de lectores que suele leer de forma independiente. Sin embargo son contados los libros infantiles dirigidos a las primeras edades (de aprestamiento escolar y primer grado) que buscan generar una experiencia estética a través de las ilustraciones. El uso funcional y no estético de las ilustraciones está asociado a la creencia extendida de que las imágenes facilitan la lectura (no se contempla que le agreguen complejidad) y que entre más pronto el niño o la niña abandone los libros ilustrados, más rápido se sumergirá en la literatura "seria" y "formal".

La lectura de imágenes no ha sido muy valorada ni estimulada. Sobre esto, el ilustrador y maestro, Lonnie Ruiz ${ }^{9}$ puntualiza: “(...) en el aula de clase me he encontrado a estudiantes a quienes les muestro imágenes geométricas, les pregunto ¿qué ven ahí? y se limitan a ver lo que está explícito: un círculo es un círculo. Pero ¿por qué no puede ser el fondo de un túnel, una sombrilla vista desde arriba o un gordito tomando el sol? (...) el problema es que van a ser incapaces de imaginar otras soluciones".

Otro aspecto que dificulta la producción de estos libros está vinculado a lo que éstos demandan en el acompañamiento lector: "Darle un libro, una cosa súper fácil, Disney, lleno de imágenes acartonadas, hace que el adulto se pueda desligar más fácilmente del niño, mientras que el álbum ilustrado te propone establecer diálogo, y en ese sentido se genera una interacción que tal vez en otros formatos no es de esa manera”, afirma Alberto Sánchez ${ }^{10}$.

El texto mantiene un discurso que la imagen refuerza o contradice. La lectura de ambas dimensiones del lenguaje permite descodificar el mensaje, haciéndonos menos propensos a la 'manipulación publicitaria', que trabaja particularmente a través de las imágenes. Según Sánchez, "el álbum ilustrado forma lectores porque procura una experiencia estética valiosa para las y los niños neo-lectores que en un futuro asociarán el acto de la lectura como un gozo".

La visión utilitarista y racionalista de la literatura infantil, la escasa consideración hacia las imágenes y la falta de consumo masivo de estos libros hacen que las ediciones nicaragüenses sean modestas en cuanto a tiraje y materiales. Sin embargo, hay libros que con creatividad logran superar estas desventajas.

"Nosotros siempre hablamos de cierta calidad en la ilustración y de cierta calidad en el texto para que el niño se enamore de los libros y sentíamos que los libros que existían en Nicaragua no iban a proporcionar ese enamoramiento que nosotros queríamos que hubiera entre niños y libros” afirma Gabriela Tellería Picón ${ }^{11}$, de Libros para Niños. Y si bien - según Tellería - hacer álbumes ilustrados no es el propósito de este fondo editorial, la ilustración no es vista como un elemento

9 Lonnie Ruiz (1982). Diseñador e ilustrador, docente universitario. www.lonnieruiz.com. Citado en este artículo según entrevista concedida en junio 2015 para este trabajo de investigación.

10 Alberto Sánchez Argüello (1976) es psicólogo, docente, ilustrador y escritor nicaragüense. También es coordinador de la Asociación de Ilustradores de Nicaragua. En Facebook: Colectivo de Ilustradores de Nicaragua. Citado en este artículo según entrevista concedida en junio de 2015 para este trabajo de investigación.

11 Gabriela Tellería Picón es Coordinadora del Fondo Editorial Libros para Niños. Citada en este artículo según entrevista otorgada en abril 2015. 
decorativo en los libros infantiles que producen. Esto desemboca en publicaciones que, sin llegar a ser álbumes ilustrados en el sentido estricto de la interacción texto, imagen y soporte, en algunas de sus páginas exhiben características y modos de expresión propios del álbum.

\section{Selección del corpus de 'álbumes ilustrados' en Nicaragua}

El álbum ilustrado, se comienza a desarrollar a partir del año 2007 con 'Un naufragio inesperado', de Ulises Salazar y Lonnie Ruiz, y publicado por Libros para Niños, fondo editorial que aporta casi la mitad de la producción de literatura infantil de Nicaragua. El catálogo de esta editorial está clasificado según las etapas del desarrollo en la lectura: a neolectores, para quienes leen palabras y para lectores. La temática de sus publicaciones se enfoca en el folclore nicaragüense y el acervo cultural de los pueblos indígenas. Destacan los libros de Nivio y María López Vigil y la colección 'Taira'. Esta última recopila cuatro cuentos de la tradición oral misquita, en ediciones bilingües. Además, las publicaciones de este fondo editorial han incursionado en temas como la muerte, la migración, el trabajo infantil y la fantasía, sin los infantilismos que muchas veces se encuentran en algunos libros de la producción nacional.

Se han identificado (hasta abril de 2015) $84^{12}$ libros con ISBN y 1 que se publicó de forma individual sin ISBN.

\section{Análisis de las publicaciones seleccionadas: ¿álbumes ilustrados?}

Los criterios de selección fueron: número reducido de páginas (38 el máximo), la mayoría de éstas ilustradas (a través de página o doble página: bisagra), mayor parte del espacio ocupado por la ilustración, la función de la ilustración y la relación entre texto e imagen.

En cuanto a la función de la ilustración, se comprende 'abrazada' como una relación fusionada entre texto e imagen, y 'complementaria' como una relación meramente colaborativa entre texto e imagen.

12 Dato obtenido de la Oficina de Adquisiciones de la Biblioteca Nacional Rubén Darío. Esta oficina es la encargada de otorgar el número ISBN para las publicaciones nicaragüenses. 
El corpus que se obtiene consta de 12 publicaciones:

\begin{tabular}{|c|c|c|c|c|c|c|}
\hline Titulo & $\begin{array}{c}\text { Número } \\
\text { de } \\
\text { páginas }\end{array}$ & $\begin{array}{c}\text { Número } \\
\text { de } \\
\text { páginas } \\
\text { ilustradas }\end{array}$ & $\begin{array}{c}\text { Espacio } \\
\text { ocupado por } \\
\text { la ilustración } \\
\text { en la página }\end{array}$ & Soporte & $\begin{array}{l}\text { Función de la } \\
\text { ilustración }\end{array}$ & \begin{tabular}{|c} 
Relación \\
entre texto \\
e imagen
\end{tabular} \\
\hline $\begin{array}{l}\text { Un naufragio } \\
\text { inesperado }\end{array}$ & 18 & 18 & $\begin{array}{l}8 \text { bisagras } \\
2 \text { páginas }\end{array}$ & $\begin{array}{l}\text { Libro: } 8.5 \text { de ancho } \\
\text { por } 9.5 \text { de alto }\end{array}$ & Abrazada & $\begin{array}{l}\text { Complicidad } \\
\text { entre texto e } \\
\text { imagen. }\end{array}$ \\
\hline $\begin{array}{l}\text { Gonzalo el } \\
\text { cocodrilo / } \\
\text { historia de } \\
\text { dos sapos }\end{array}$ & 24 & 24 & 12 bisagras & $\begin{array}{l}\text { Libro: } 8.5 \text { de ancho } \\
\text { por } 9.5 \text { de alto. } \\
\text { Libro dos en uno }\end{array}$ & Complementaria & $\begin{array}{l}\text { Imagen } \\
\text { supeditada } \\
\text { al texto }\end{array}$ \\
\hline A Margarita & 28 & 28 & 14 bisagras & $\begin{array}{l}\text { Libro: } 6 \text { de ancho } \\
\text { por } 6 \text { de alto }\end{array}$ & Complementaria & \begin{tabular}{|l} 
Imagen \\
supeditada \\
al texto \\
\end{tabular} \\
\hline Sapos & 20 & 20 & $\begin{array}{l}9 \text { bisagras, } 2 \\
\text { páginas }\end{array}$ & $\begin{array}{l}\text { Libro: } 8 \text { de ancho } \\
\text { por } 8 \text { de alto }\end{array}$ & Abrazada & $\begin{array}{l}\text { Complicidad } \\
\text { entre texto e } \\
\text { imagen. }\end{array}$ \\
\hline $\begin{array}{l}\text { Elefante } \\
\text { solitario }\end{array}$ & 20 & 20 & 10 bisagras & $\begin{array}{l}\text { Libro: } 6.5 \text { de ancho } \\
\text { por } 7 \text { de alto }\end{array}$ & Abrazada & $\begin{array}{l}\text { Complicidad } \\
\text { entre texto e } \\
\text { imagen. }\end{array}$ \\
\hline $\begin{array}{l}\text { Los Cantos del } \\
\text { grillo }\end{array}$ & 14 & 14 & 7 bisagras & $\begin{array}{l}\text { Libro: } 9 \text { de ancho } \\
\text { por } 8 \text { de alto }\end{array}$ & Abrazada & $\begin{array}{l}\text { Complicidad } \\
\text { entre texto e } \\
\text { imagen. }\end{array}$ \\
\hline La luna y yo & 20 & 20 & $\begin{array}{l}9 \text { bisagras, } 2 \\
\text { páginas }\end{array}$ & $\begin{array}{l}\text { Libro: } 6 \text { de ancho } \\
\text { por } 6 \text { de alto }\end{array}$ & Complementaria & \begin{tabular}{|l} 
Imagen \\
supeditada \\
al texto
\end{tabular} \\
\hline $\begin{array}{l}\text { Donde nacen } \\
\text { las sirenas }\end{array}$ & 36 & 36 & 18 bisagras & $\begin{array}{l}\text { Libro de pasta dura: } \\
10.5 \text { de ancho por } \\
8.5 \text { de alto }\end{array}$ & Complementaria & \begin{tabular}{|l} 
Imagen \\
supeditada \\
al texto
\end{tabular} \\
\hline $\begin{array}{l}\text { Mi gato } \\
\text { Mostacho }\end{array}$ & 24 & 24 & $\begin{array}{l}9 \text { bisagras, } 6 \\
\text { páginas }\end{array}$ & $\begin{array}{l}\text { Libro: } 7.5 \text { de ancho } \\
\text { por } 8.5 \text { de alto }\end{array}$ & Complementaria & \begin{tabular}{|l} 
Imagen \\
supeditada \\
al texto
\end{tabular} \\
\hline $\begin{array}{l}\text { Mi amigo el } \\
\text { dragón }\end{array}$ & 20 & 20 & 10 bisagras & $\begin{array}{l}\text { Libro: } 7.5 \text { de ancho } \\
\text { por } 9 \text { de alto }\end{array}$ & Complementaria & \begin{tabular}{|l} 
Imagen \\
supeditada \\
al texto \\
\end{tabular} \\
\hline $\begin{array}{l}\text { El caballito de } \\
\text { palo }\end{array}$ & 22 & 22 & 11 bisagras & $\begin{array}{l}\text { Libro: } 7.5 \text { de ancho } \\
\text { por } 8.5 \text { de alto. } \\
\text { Edición especial de } \\
250 \text { ejemplares en } \\
\text { pasta dura }\end{array}$ & Complementaria & $\begin{array}{l}\text { La imagen } \\
\text { acompaña al } \\
\text { texto }\end{array}$ \\
\hline $\begin{array}{l}\text { Los monstruos } \\
\text { bajo la cama }\end{array}$ & 13 & 13 & 13 páginas & Libro digital & Complementaria & \begin{tabular}{|l} 
La imagen \\
acompaña al \\
texto
\end{tabular} \\
\hline
\end{tabular}


Encuentro No. 104, 53-80, 2016

'Un naufragio inesperado', escrito por Ulises Salazar e ilustrado por Lonnie Ruiz. Las ilustraciones en 'Un naufragio inesperado', otorgan momentos como el que se sugiere en las páginas 9, 10 y 11, (fig. 2 y 3). A través de las imágenes se da a entender que la señora que ordena la casa es una ballena, a pesar de que el texto no lo diga de manera explícita.

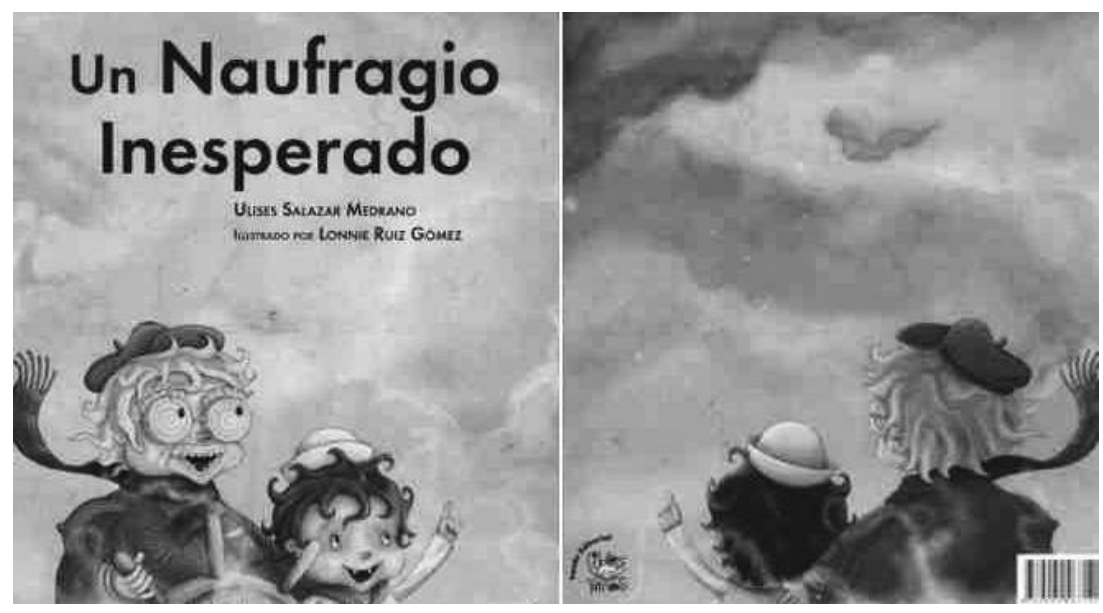

Fig. 1: Portada y contraportada de 'Un naufragio inesperado'

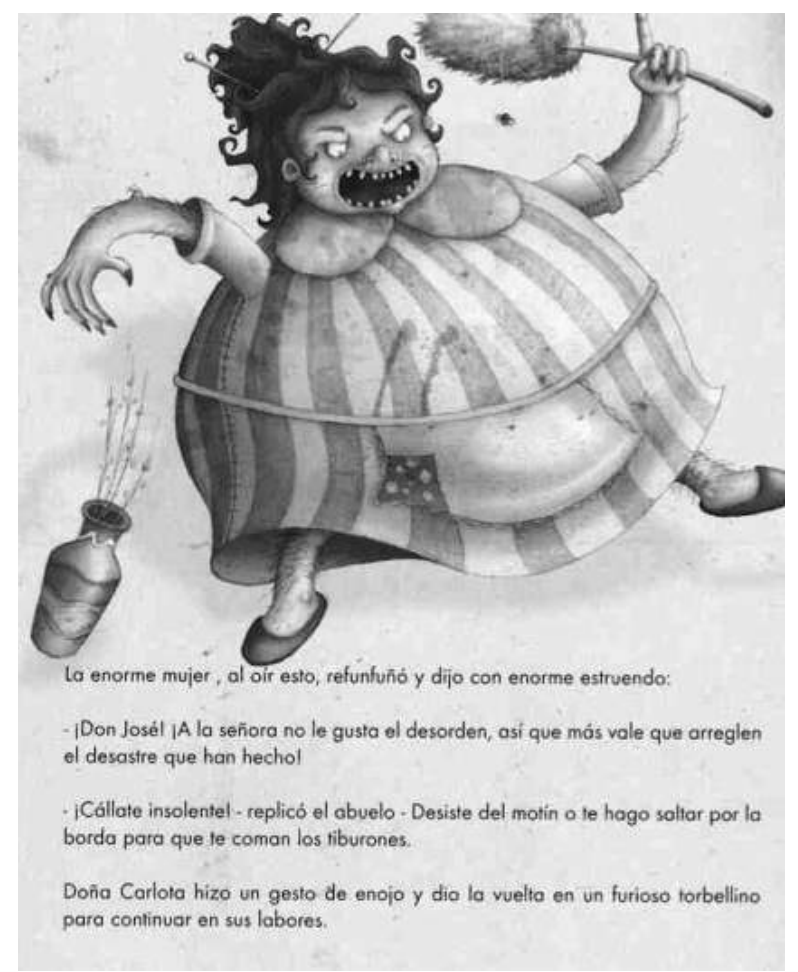

Fig. 2: Página 11 de 'Un naufragio inesperado' 

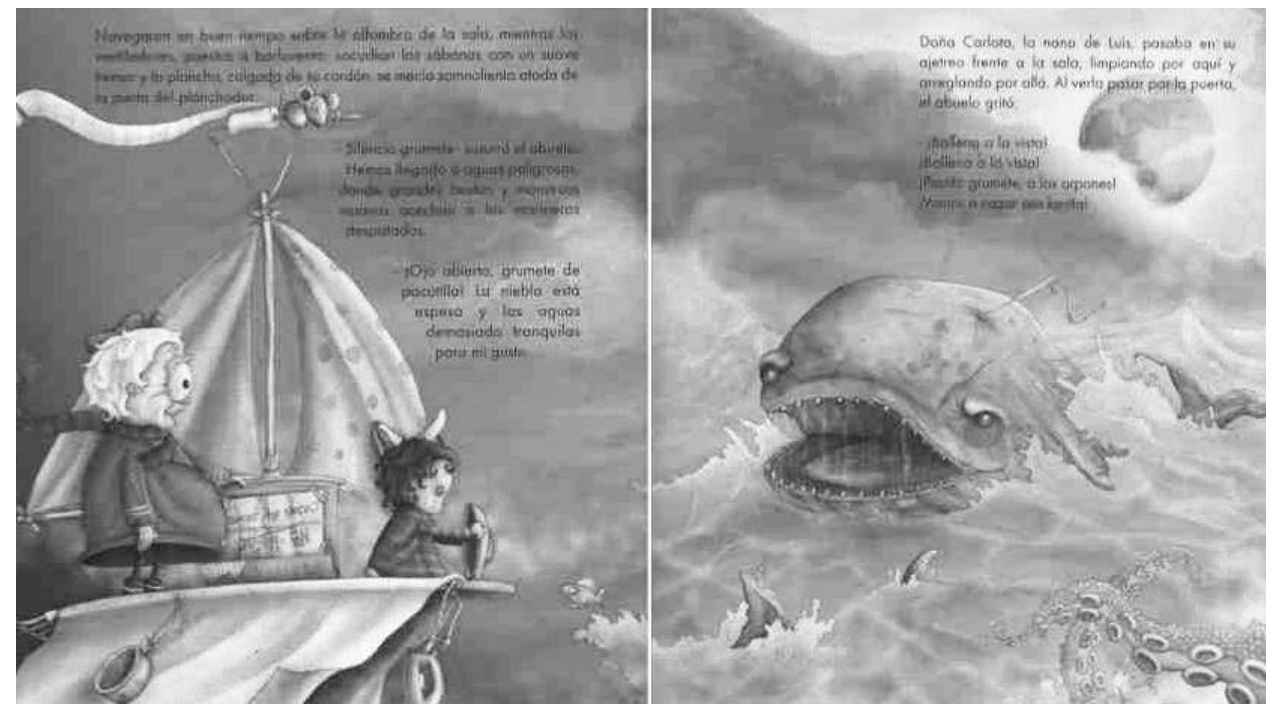

Fig. 3: Páginas 9 y 10 de 'Un naufragio inesperado'

'Gonzalo el cocodrilo' / 'Historia de dos sapos' de Mario Montenegro y Álvaro Borrasé, cuenta dos historias: la primera es sobre un cocodrilo comelón que se convierte en titiritero. La segunda es sobre una pareja de sapos que son criticados por sus ropas extravagantes.

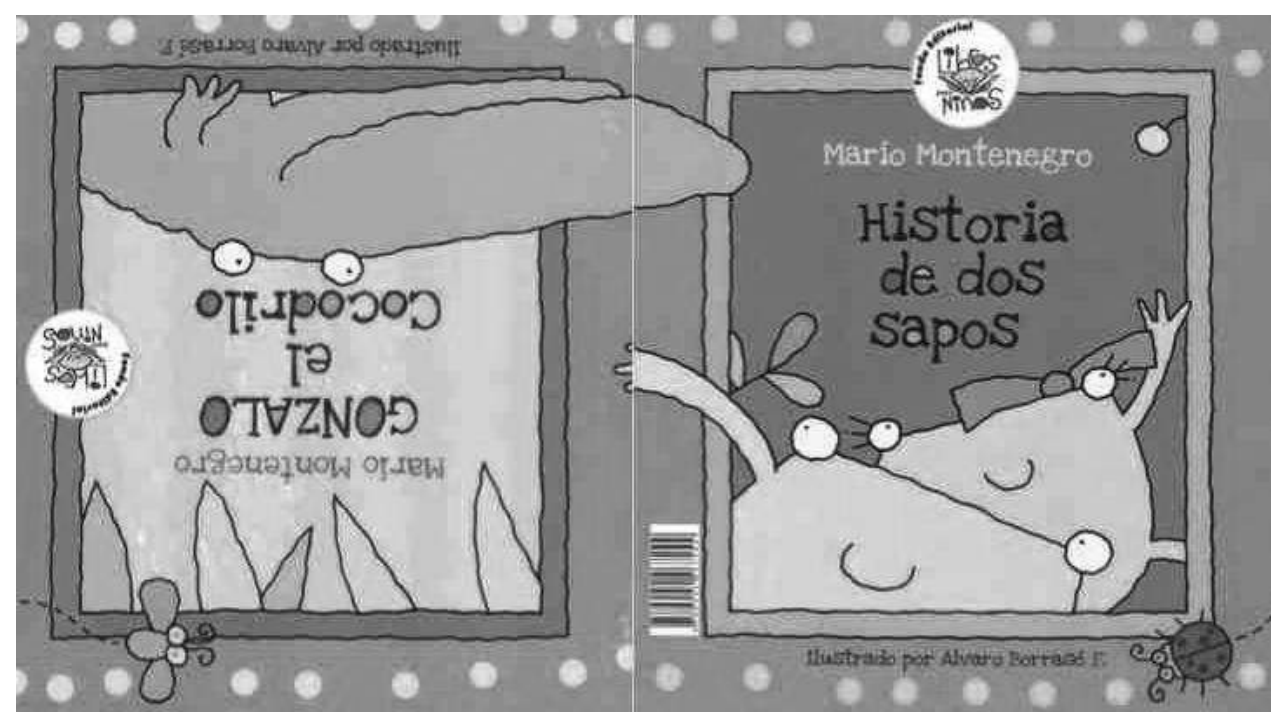

Fig. 4: Portada y contraportada de 'Gonzalo el cocodrilo' e 'Historia de dos sapos' 
Encuentro №. 104, 53-80, 2016

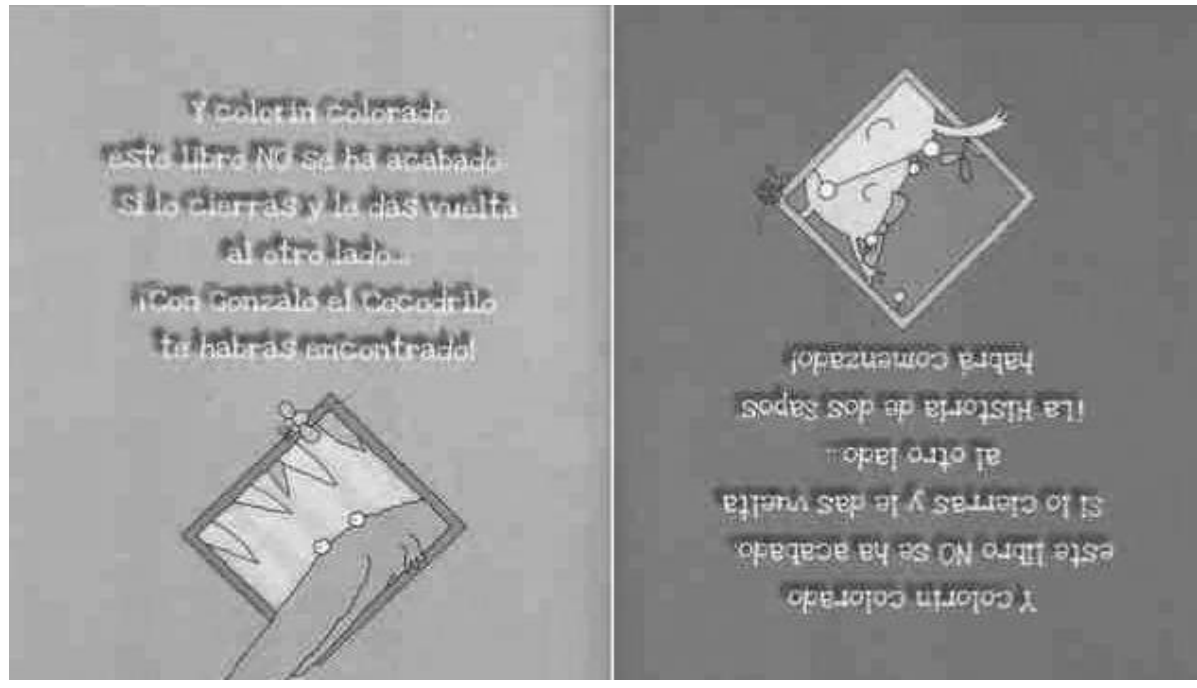

Fig. 5: páginas 13 y 14 de 'Gonzalo el cocodrilo' / 'Historia de dos sapos'

La forma en la que son presentadas ambas historias hacen del 'dispositivo libro' algo más interactivo. Al llegar al final de cada cuento se invita al lector a invertir el libro para poder leer el otro cuento (Fig. 5). El texto de ambas historias es breve y de las 24 páginas que lo conforman todas están ilustradas.

'A Margarita', del poeta modernista Rubén Darío e ilustrado por Álvaro Borrasé. En algunos casos la imagen está supeditada al texto, sin embargo, algunas ilustraciones sugieren interpretaciones valiosas como la presencia de princesas de otras culturas (fig. 8) o invitan a girar la página con el movimiento del personaje (fig. 7). En la portada (fig. 6) se muestra a la princesa y en la contraportada a la niña que escuchará la historia (puede ser Margarita).

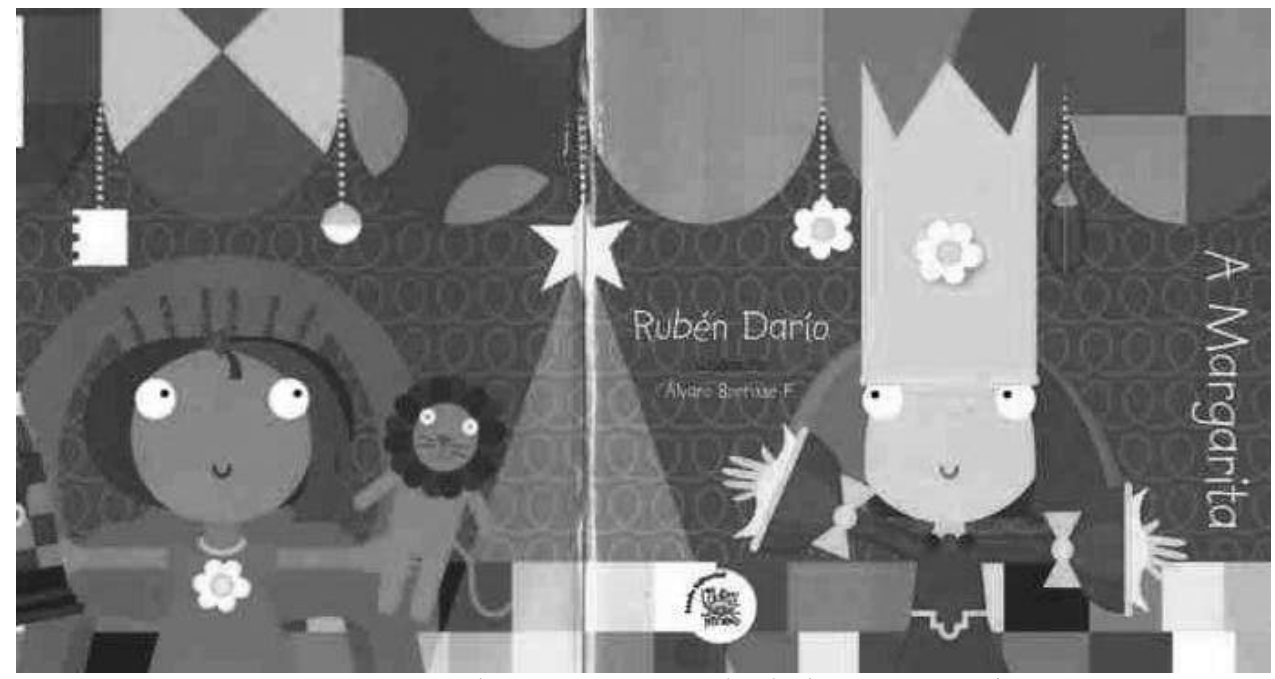

Fig. 6: Portada y contraportada de 'A Margarita' 


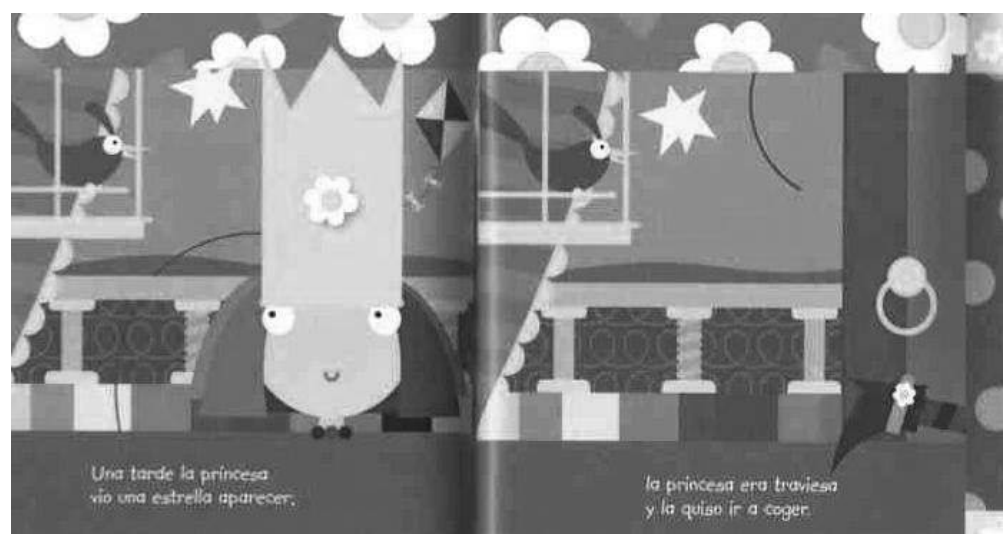

Fig. 7: Páginas 5 y 6. 'A Margarita'

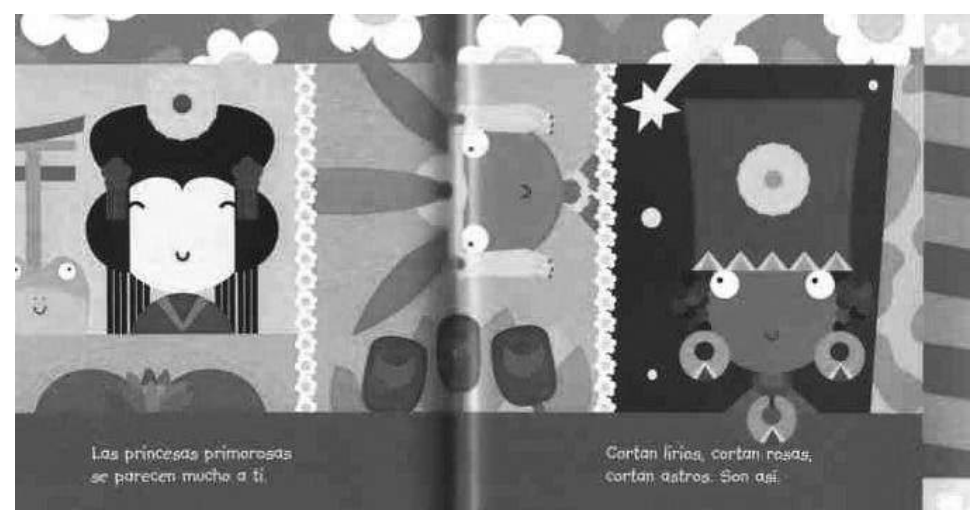

Fig. 8: Páginas 9 y 10. 'A Margarita'

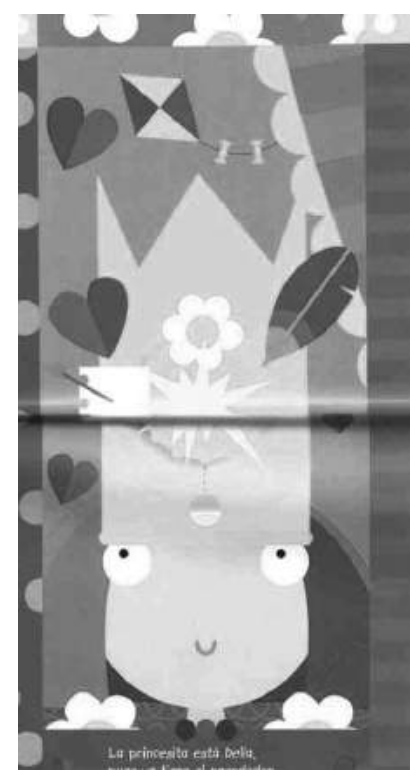

Fig. 9: Páginas 27 y 28. 'A Margarita' 
Encuentro №. 104, 53-80, 2016

La figura 9 corresponde a un giro que se propone desde el diseño. Esto hace que se rompa el ritmo al cual el lector se había habituado.

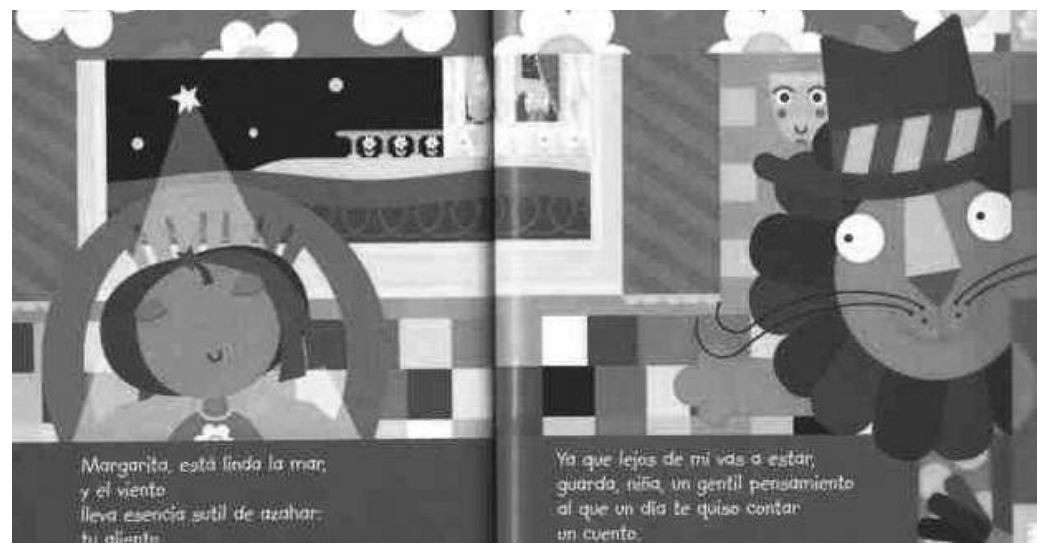

Fig. 10: Páginas 29 y 30. 'A Margarita'

En esta bisagra (fig. 10) se muestra al rey y a la princesa (ubicados en el centro) velar el sueño de Margarita. La presencia de Darío es recurrente y simbolizada por el León.

'Sapos' escrito e ilustrado por Lonnie Ruiz. El libro funciona como un álbum de sapos. El texto es sumamente breve. Las guardas (fig. 12 y 13) invitan a descubrir el elemento que es diferente, justo en la misma línea de la historia de 'Sapos', en donde sus personajes son todos distintos pero comparten algo en común.

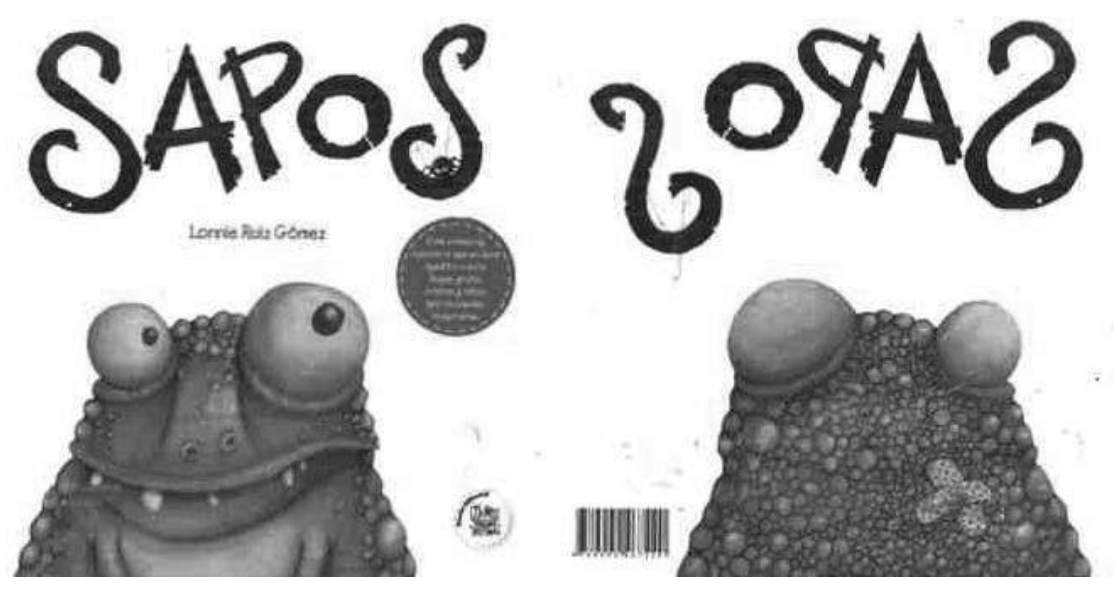

Fig. 11: Portada y contraportada de 'Sapos' 


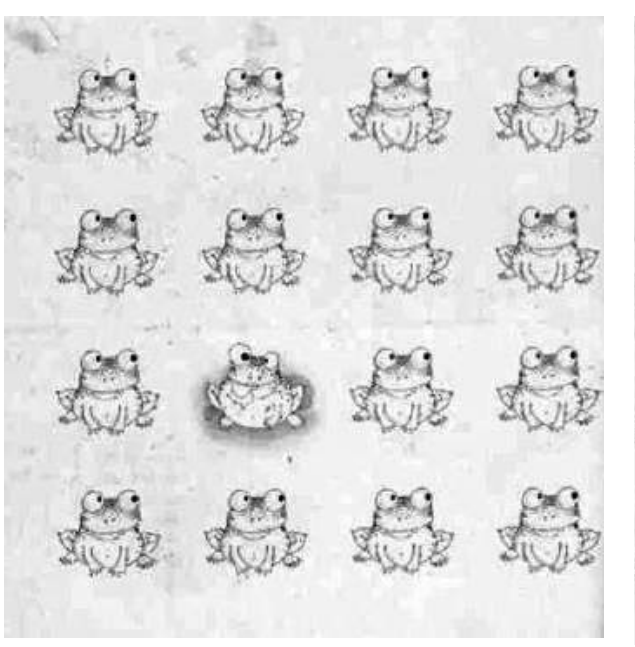

Fig. 12: Guarda contigua a la portada de 'Sapos'

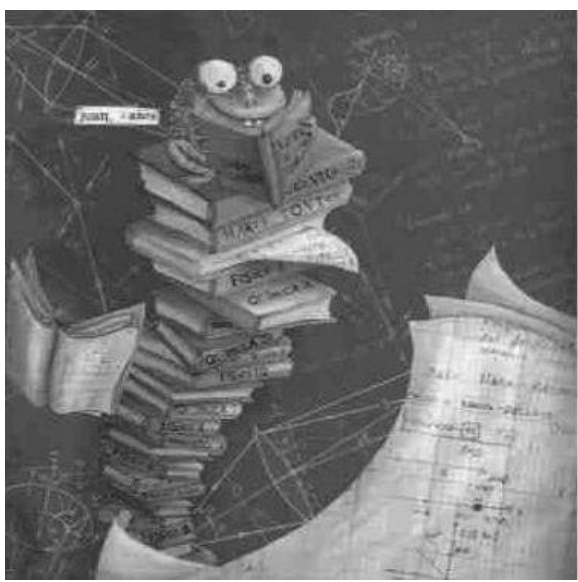

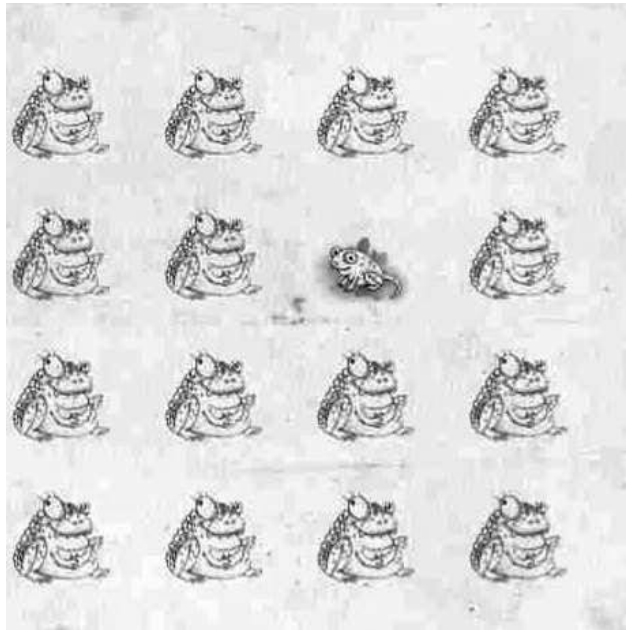

Fig. 13: Guarda contigua a la contraportada de 'Sapos'

Fig. 14: Páginas 3 y 4 de 'Sapos'. Texto: "En la escuela le decían que era un gran fastidioso, pero no hay que juzgar: es un sapito estudioso"

Cada ilustración esconde detalles que permiten al lector interpretar ciertas pistas, para comprender la personalidad del sapo en mención, más allá de lo que las palabras dicen (fig. 14).

En 'Elefante solitario' el texto surge de una canción de media página, de Salvador Cardenal, que expresa el amor de un padre hacia sus hijos. El libro fue diseñado e ilustrado por Lonnie Ruiz. En su reimpresión (2011) pasa a 6.5 pulgadas de ancho por 7 de alto. Esto favorece a este libro, como objeto, porque lo hace algo más íntimo y manipulable. Las ilustraciones, a pesar de los detalles, tienen muchos espacios vacíos, los que se aprecian mejor al disminuir de tamaño y se pueden interpretar como 'silencios', necesarios para valorar las pistas escondidas en cada bisagra. 
Encuentro №. 104, 53-80, 2016

\section{Elefante solitario}

Salvador Cardenal Barquero

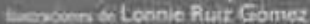

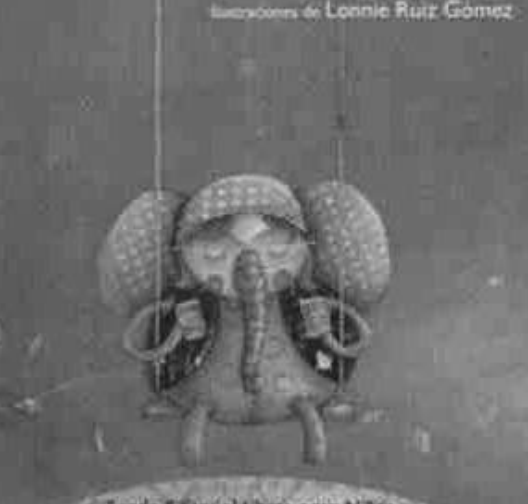

Fig. 15: Portada y contraportada de 'Elefante solitario'

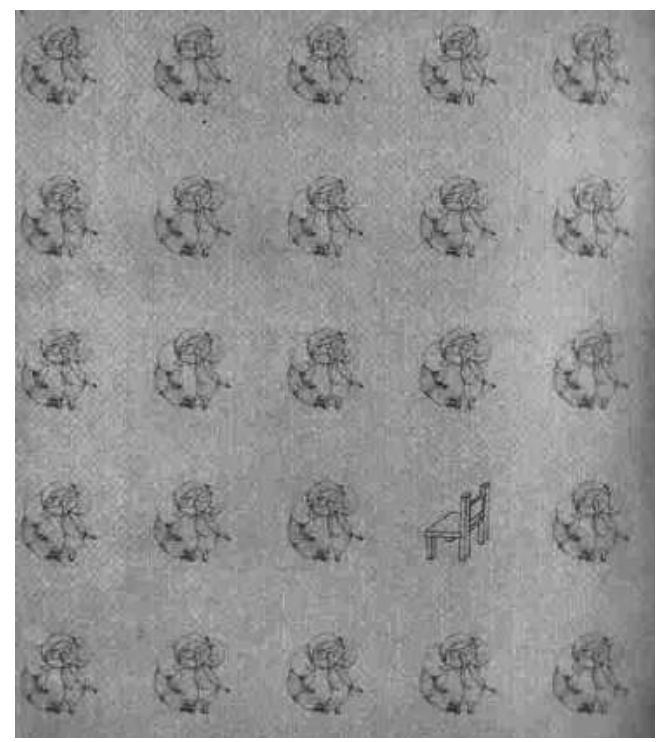

Fig. 16: Guarda de 'Elefante solitario'.

En ella se esconde una silla vacía, la cual simboliza la soledad.

Las escenas están representadas como una obra de teatro. El elemento que invita a girar la página es la fotografía de los hijos de Cardenal, la cual se presenta siempre de forma diferente en cada bisagra (fig. 17) 


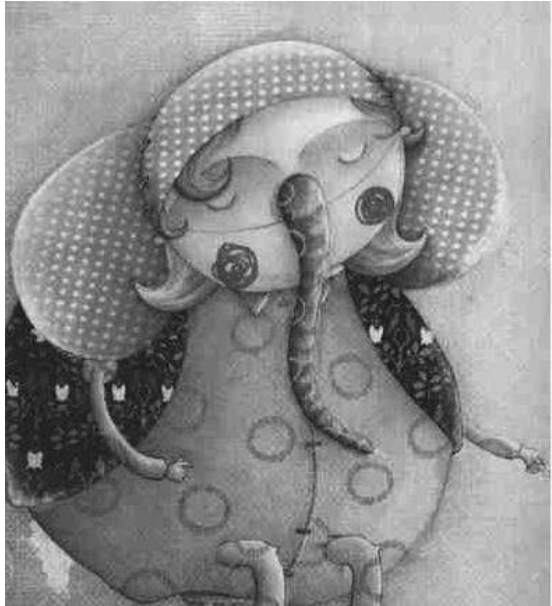

\section{Soy un Elefante solitario}

Fig. 17: Página 7 y 8 de 'Elefante solitario'.

En las sillas vacías aparecen las fotos de sus hijos

'Cantos del grillo', escrito por Óscar Corea, está compuesto por 10 poemas y fue ilustrado en el 2009 por Alicia Zamora y en el 2013 por Ruth Angulo.
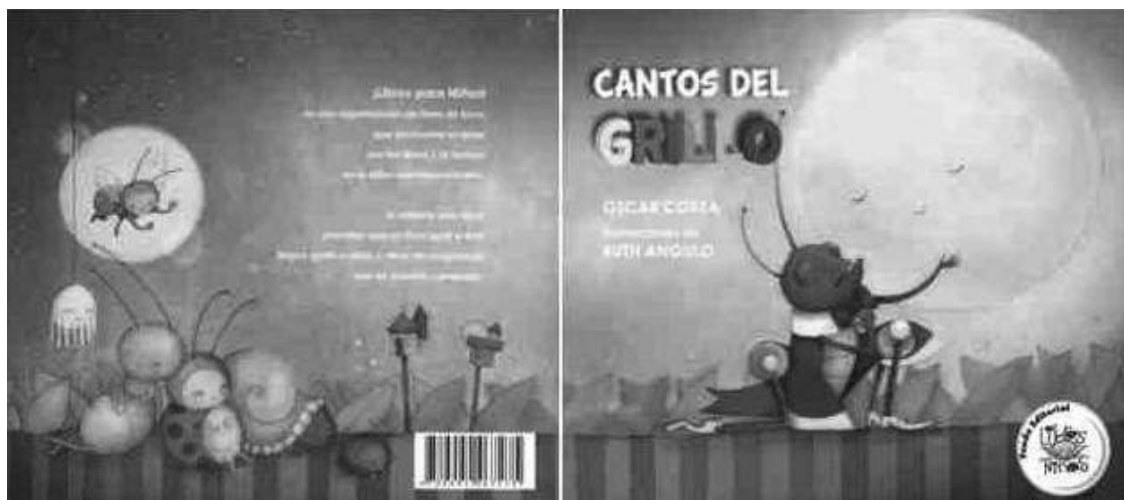

Fig. 18: Portada y contraportada 'Cantos del grillo' (2013)

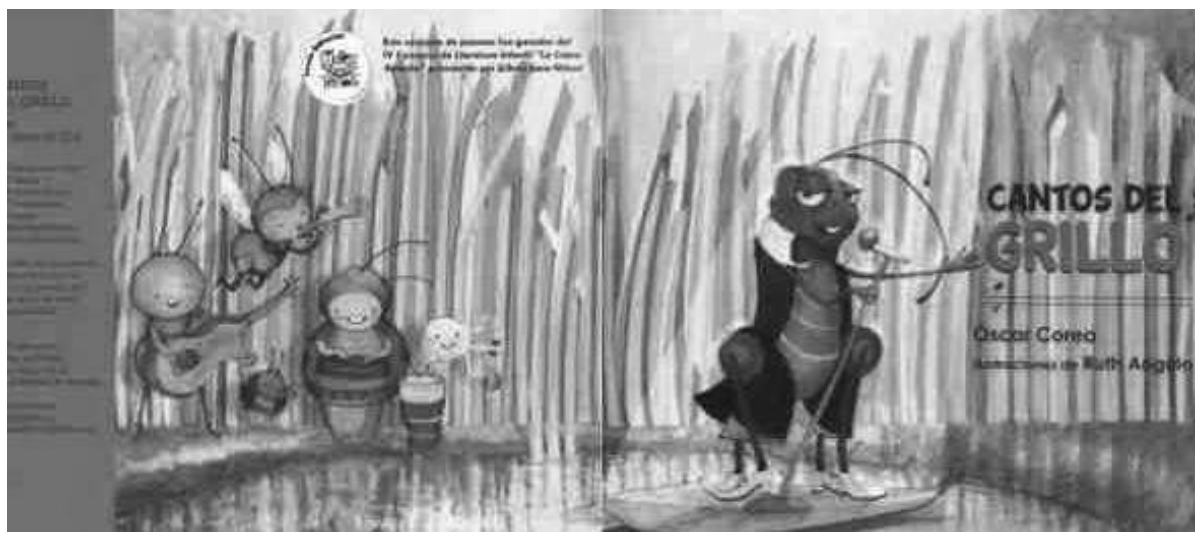

Fig. 19: Guarda contigua a la portada 'Cantos del grillo' (2013) 
Encuentro №. 104, 53-80, 2016
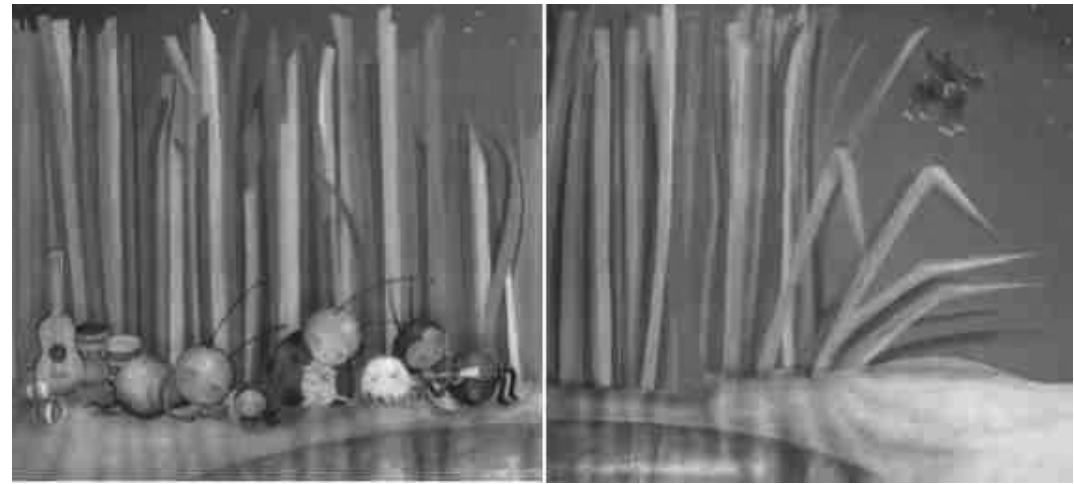

Fig. 20: Guarda contigua a la contraportada 'Cantos del grillo' (2013)

La edición de 2013 logra reunir algunos elementos que hacen que la obra apunte más a las características del álbum ilustrado. De las 14 páginas que lo conforman, todas están ilustradas (7 bisagras). Las ilustraciones son de carácter expresivo e invitan al lector a observar con detenimiento, dado el nivel de detalles. Las guardas (fig. 19 y 20) nos presentan el inicio de un concierto y el final del mismo: que consiste en lograr conciliar el sueño de los más pequeños.

'La luna y yo' de Katia Cardenal ${ }^{13}$ e ilustrado por Álvaro Borrasé ${ }^{14}$, con la brevedad del texto y el minimalismo en las imágenes otorga una simpleza valiosa para neo-lectores. El texto es una canción de cuna escrita por Cardenal. Es un libro engrapado de 6 × 6 pulgadas y puntas redondeadas, lo que facilita la manipulación por manos pequeñas. Las 20 páginas que conforman este libro están ilustradas a partir de nueve bisagras y dos páginas.

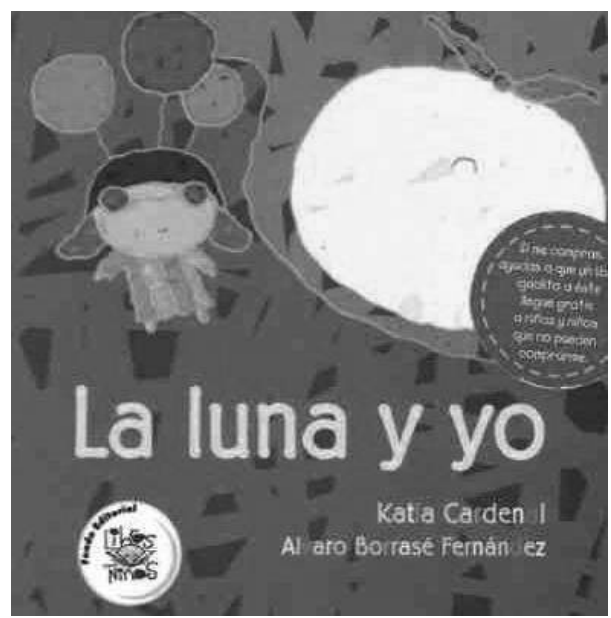

Fig. 21: Portada de 'La luna y yo' 


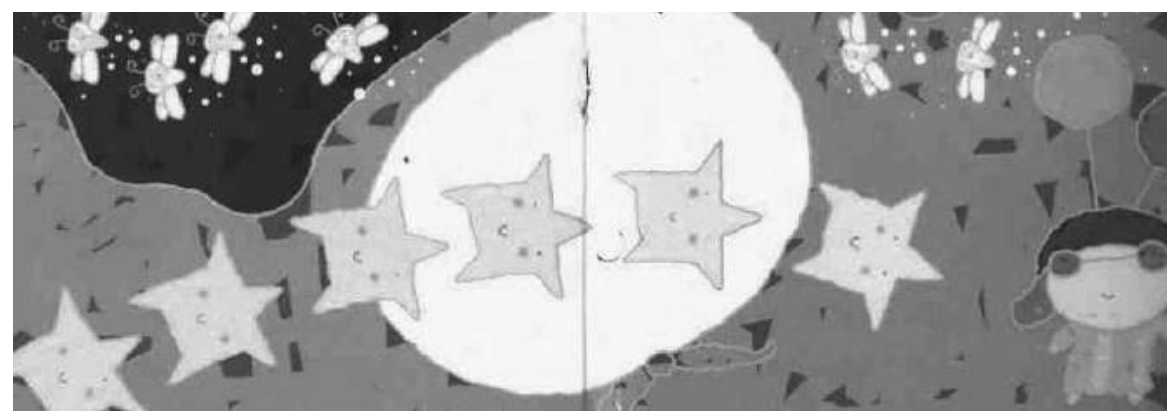

Fig. 22: Páginas 10 y 11 de 'La luna y yo'

El movimiento y ubicación de los personajes invitan a girar la página (fig. 22). También, cosas sugeridas por el texto: "Seguidas por 6 estrellas la luna y yo dibujando el camino para llegar", son representadas de forma literal por la ilustración pero también la imagen presenta otro elemento que se repite ese mismo número de veces. En este caso las luciérnagas (fig. 22).

'Donde nacen las sirenas' de Alberto Pocasangre e ilustrado por Julia Friese ${ }^{15}$, es el cuento ganador del I Concurso Centroamericano de Literatura Infantil. Según el jurado ${ }^{16}$ : "A la manera de un mito de creación contemporáneo, este hermoso cuento es una celebración de la poesía, la imaginación y la creatividad y también un valioso aporte a la literatura centroamericana para niños”.

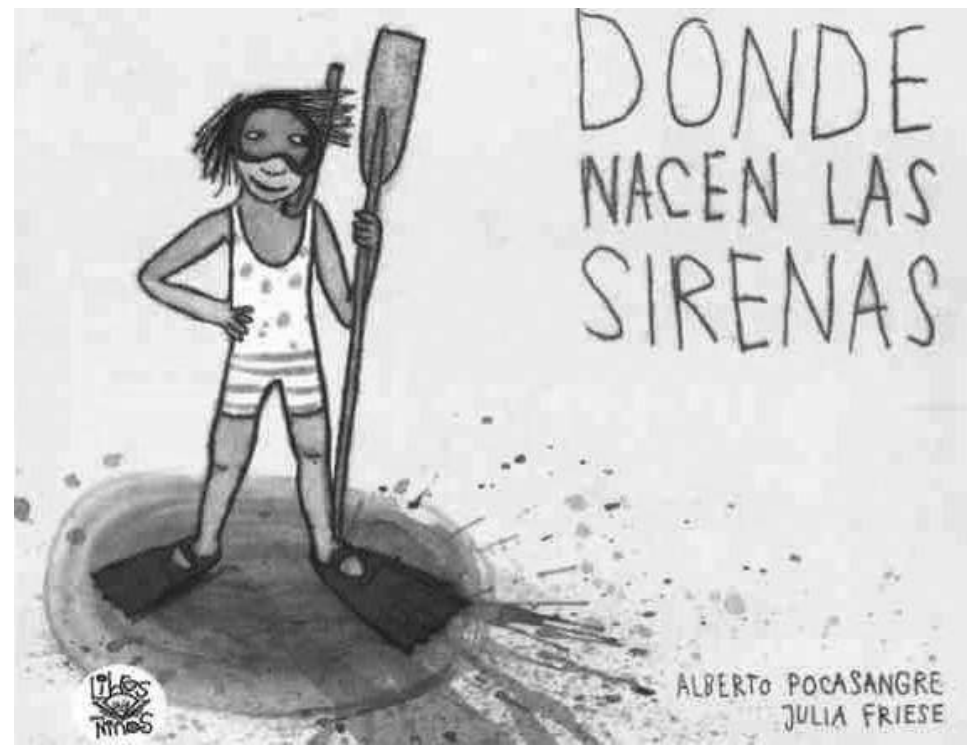

Fig. 23: Portada 'Donde nacen las sirenas'

15 Julia Friese (1979). Ilustradora y diseñadora alemana. www.juliafriese.com

16 Jurado compuesto por Irene Piedrasanta y Frieda Morales de Guatemala; Carlos Rubio y Rodolfo Dada de Costa Rica; María López y Gabriela Tellería de Nicaragua. 
Encuentro No. 104, 53-80, 2016

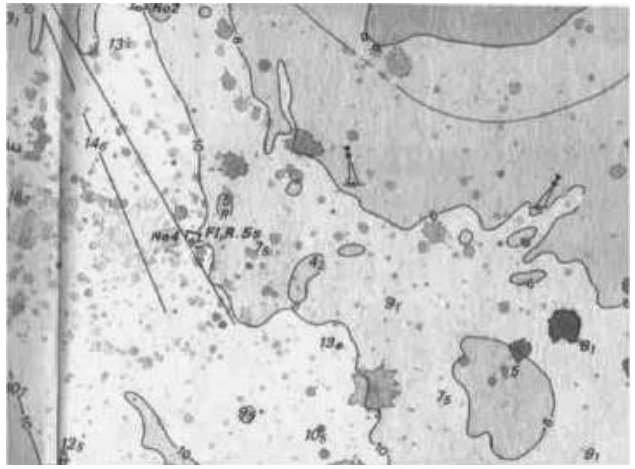

Fig. 24: Guarda contigua a la portada. 'Donde nacen las sirenas'

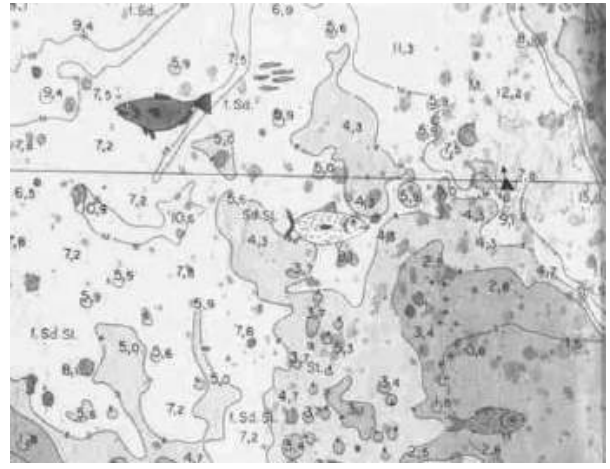

Fig. 25: Guarda contigua a la contraportada. 'Donde nacen las sirenas'

'Donde nacen las sirenas' es el libro con más páginas (36) que entra en este análisis. A pesar del número. El libro está compuesto por 18 bisagras y es de pasta dura. Los elementos que invitan a pasar la página recaen en el texto. Las guardas (fig. 24 y 25) aportan a la historia mostrando un antes y un después: se inicia con un barquito en un mar vacío y se finaliza con toda una fauna marina.

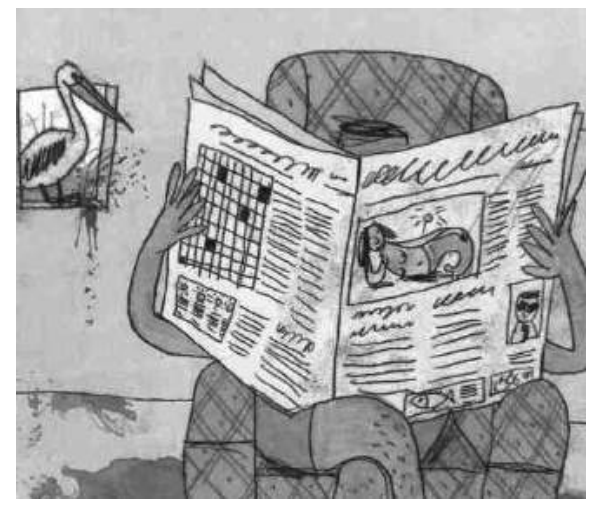

Fig. 26: Página 22. 'Donde nacen las sirenas'

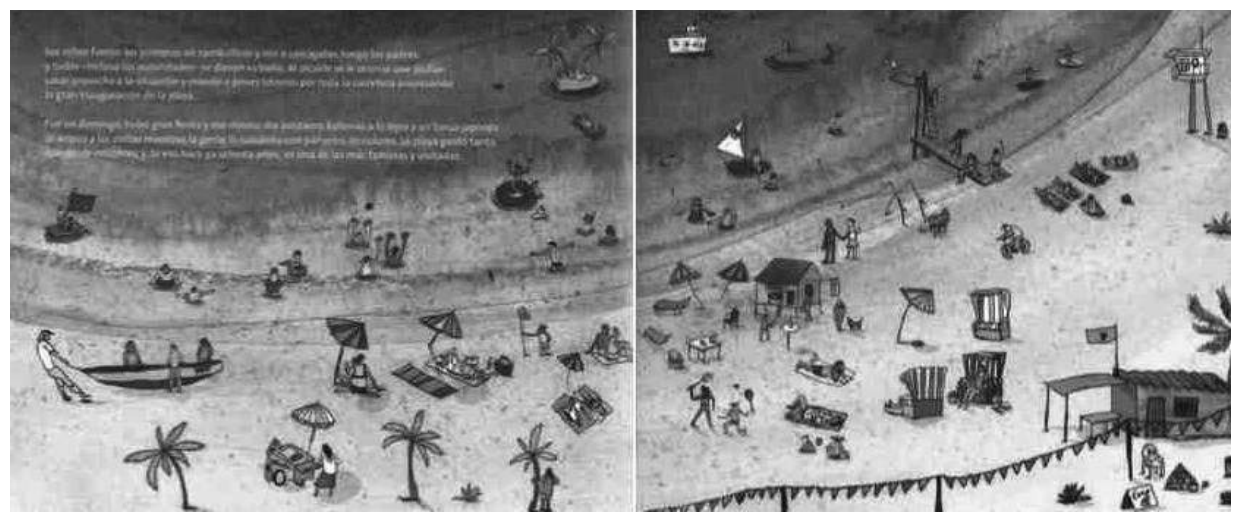

Fig. 27: Páginas 27 y 28. 'Donde nacen las sirenas' 
La historia describe a un padre displicente (fig. 26). En la figura 27 vemos una bisagra, que ejemplifica la dinámica de las ilustraciones de este cuento. En la playa cada persona hace algo diferente y el lector es invitado a detenerse para descubrirlo.

'Mi gato Mostacho', escrito por Lula Mayorga e ilustrado por Sandra Lavandeira ${ }^{17}$, es el cuento ganador de la séptima edición del concurso nacional 'La Cabra Antonia'. Este libro incursiona de manera más directa en el tema de la muerte. La ilustración sugiere de manera libre elementos como que la protagonista es una niña aunque el texto no lo diga. Hay "guiños" como la gallina y el pollo alejándose (fig. 29) que sugieren girar la página.

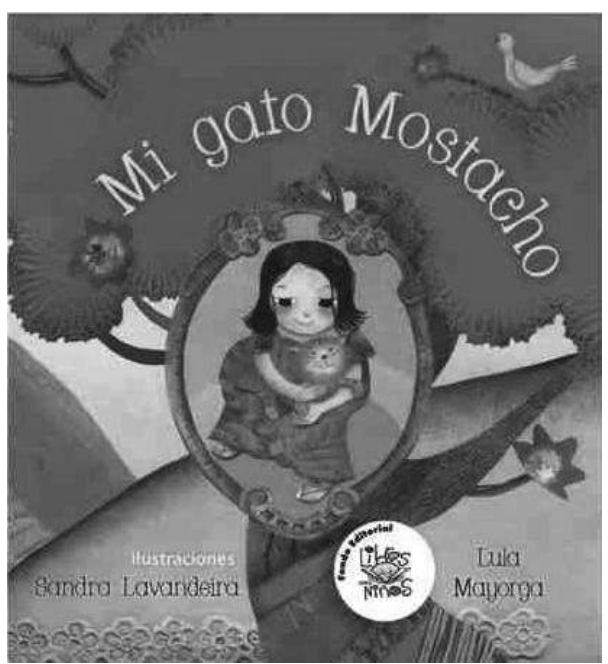

Fig. 28. Portada de 'Mi gato Mostacho'
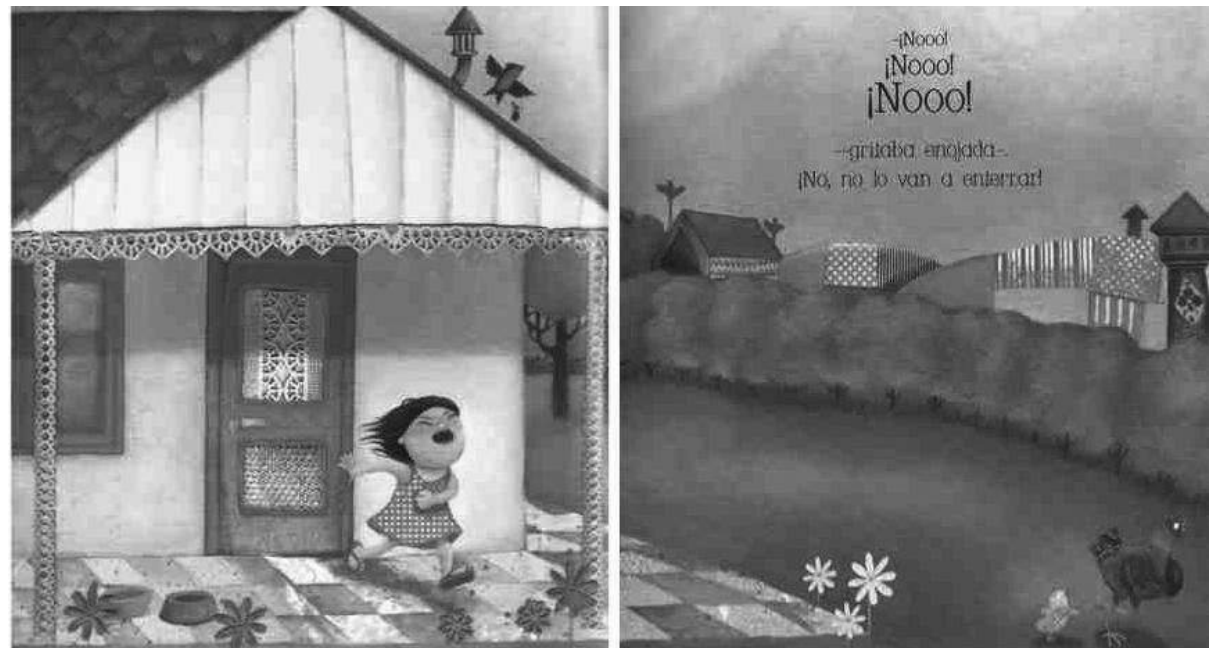

Fig. 29. Páginas 1 y 2 de 'Mi gato Mostacho'

17 Sandra Lavandeira (1965) es una ilustradora argentina radicada en Brasil. www.sandralavandeira. blogspot.com 
Encuentro №. 104, 53-80, 2016

'Mi amigo el dragón': un álbum ilustrado, escrito por Alberto Sánchez e ilustrado por Wen Hsu Chen ${ }^{18}$, propone una dinámica abrazada entre texto e ilustración. Las guardas (fig. 31 y 32) aportan a la narrativa de la historia y motivan llegar al final.

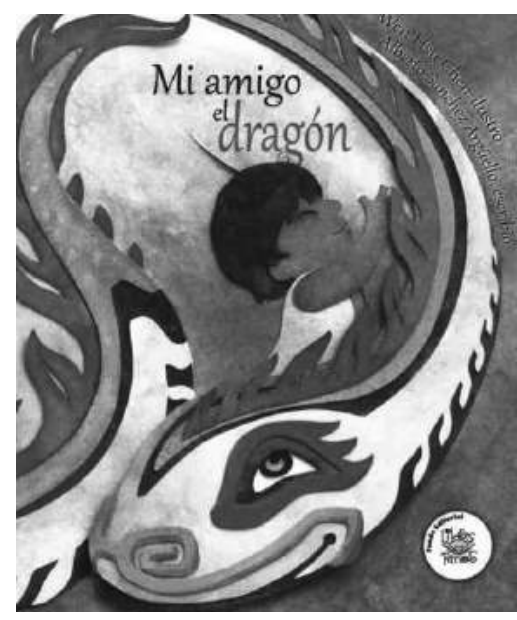

Fig. 30: Portada de 'Mi amigo el dragón'

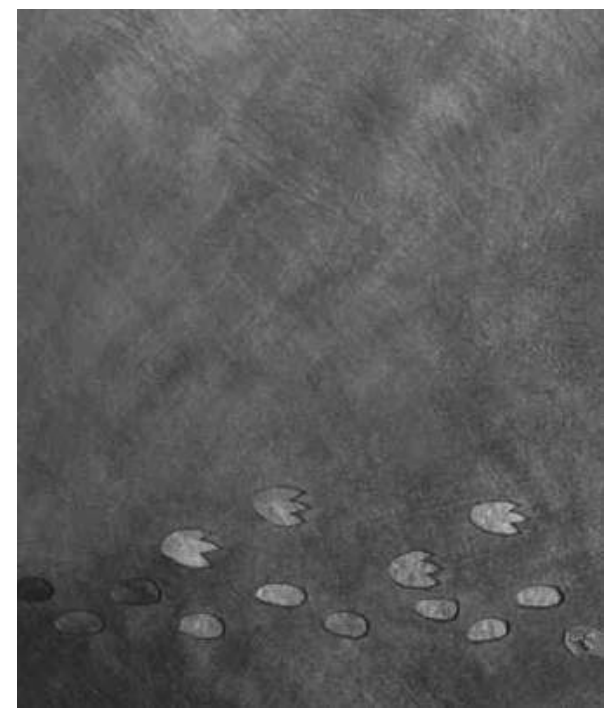

Fig. 31: parte de la guarda contigua a la portada de 'Mi amigo el dragón'

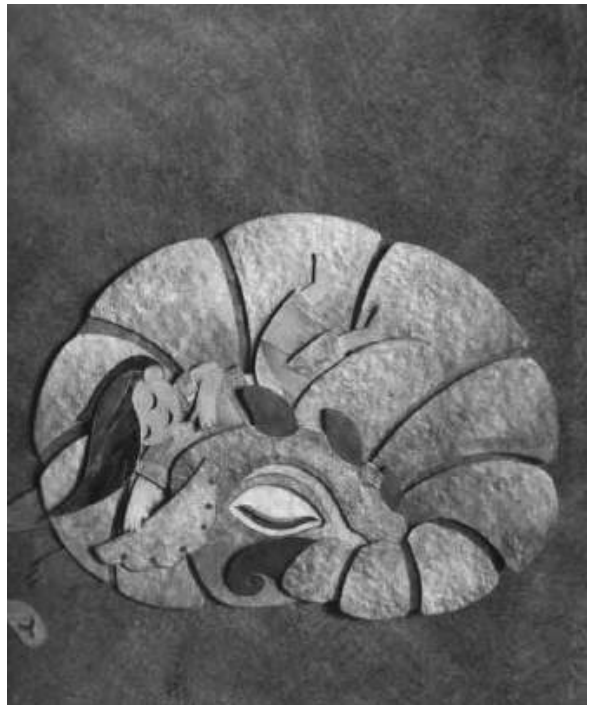

Fig. 32: parte de la guarda contigua a la contraportada de 'Mi amigo el dragón'

18 Wen Hsu Chen (1976) es una destacada ilustradora chino-costarricense. Premio NOMA para ilustradores de literatura infantil, organizado por ACCU/UNESCO en Japón, 2008. wenhsu. blogspot.com 
Con los microrrelatos como "materia prima", la ilustradora propone una serie de soluciones a las interrogantes que deja el texto, como por ejemplo ¿las pesadillas son las nubes que todos vemos en el cielo? (fig. 33) y así sucesivamente:

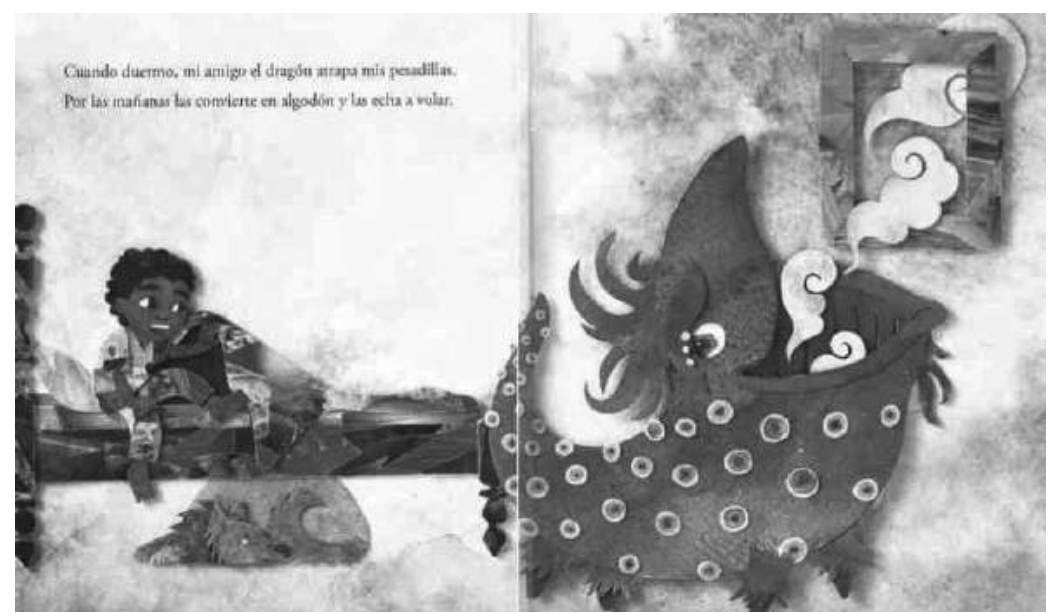

Fig. 33: Páginas 17 y 18 de 'Mi amigo el dragón'. El texto dice:

"Cuando duermo, mi amigo el dragón atrapa mis pesadillas.

Por las mañanas las convierte en algodón y las echa a volar”.

'El caballito de palo' ${ }^{19}$ de Mario Montenegro ${ }^{20}$ e ilustrado por Vicky Ramos ${ }^{21}$, con alrededor de 10,000 ejemplares vendidos, ha logrado convertirse en uno de los libros infantiles (de producción nacional) más populares en Nicaragua. En su edición especial de 250 ejemplares - correspondientes a la séptima reimpresión y de pasta dura - las guardas (fig. 35) sugieren la presencia del caballito al abrir y cerrar el libro.

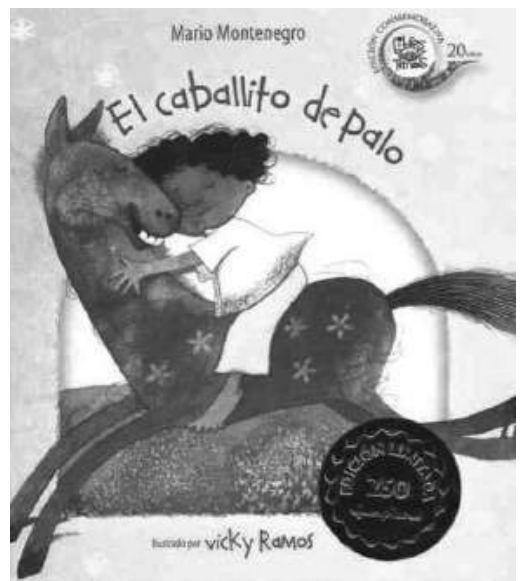

Fig. 34: Portada de 'El caballito de palo'

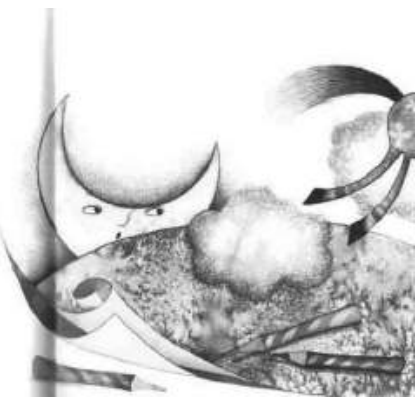

Fig. 35: Muestra de las guardas de 'El caballito de palo'

19 Séptima reimpresión a la que se hace alusión: Septiembre 2013. Impresión Comercial La Prensa.

20 Mario Montenegro (1952). Pintor, compositor y cantante nicaragüense. Se ha destacado en la producción musical dirigida a niños en Nicaragua.

21 Vicky Ramos (1960). Ilustradora y diseñadora costarricense. www.vickyramosilustra.com 
Encuentro №. 104, 53-80, 2016

Elementos como el movimiento del caballo transitando de un espacio a otro en el libro, invitan a pasar la página (fig. 37).
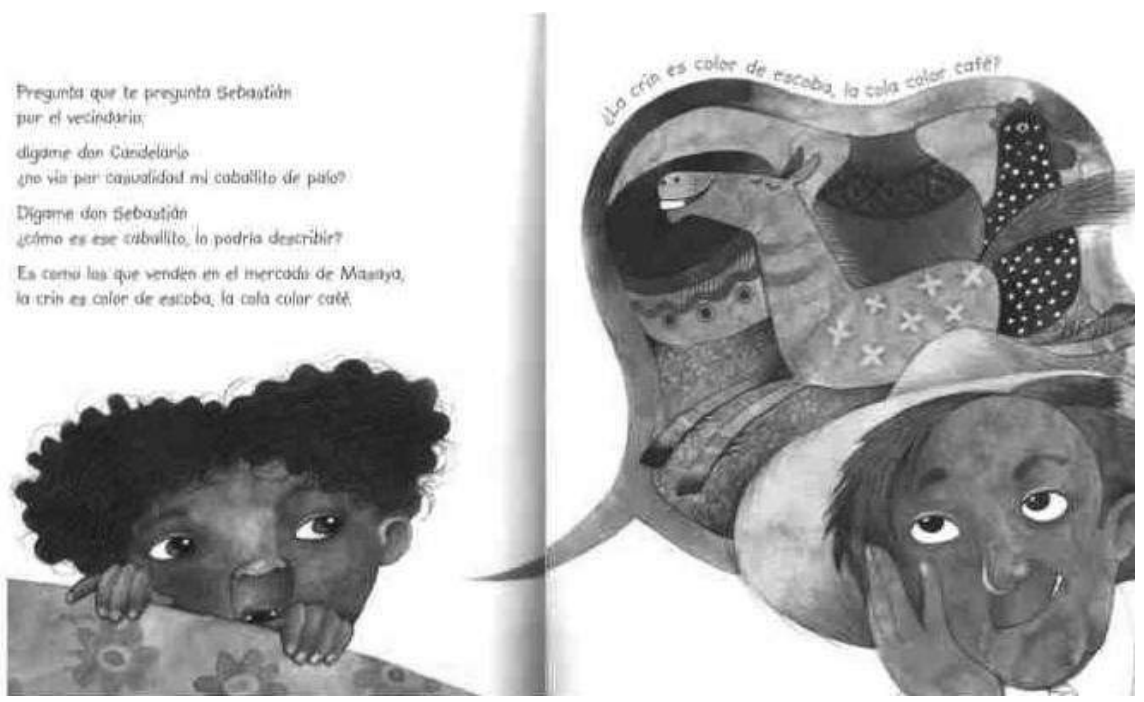

Fig. 36: Páginas 9 y 10 de 'El caballito de palo'

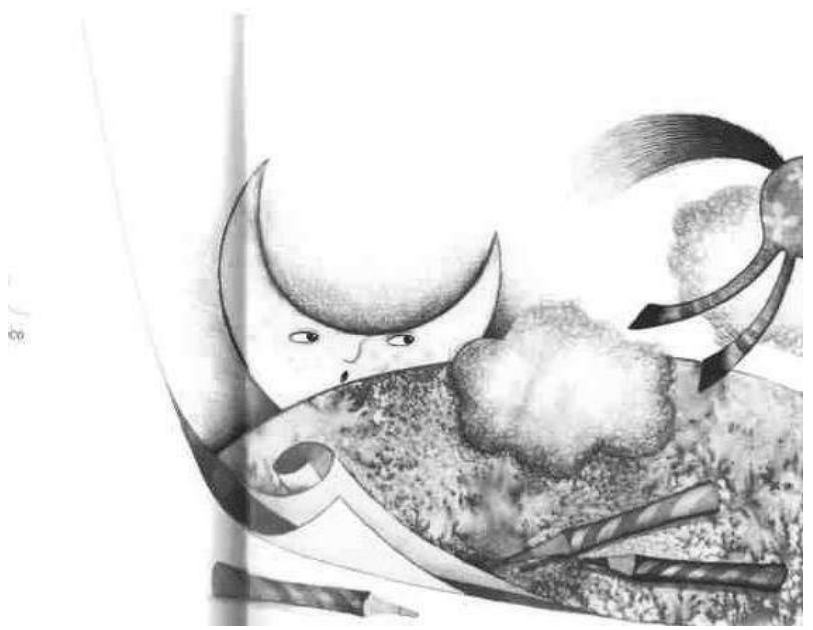

Fig. 37: Páginas 7 y 8 de 'El caballito de palo'

'Los monstruos bajo la cama', escrito e ilustrado por Alberto Sánchez Argüello, consta de 13 páginas, todas ellas ilustradas. Sánchez nos traslada a una sociedad 'civilizada' de monstruos. Como el libro reúne una serie de microrrelatos, el texto es muy breve. Los microrrelatos funcionan como premisas: son pocos los elementos que se dan, pero son los necesarios para que el lector comprenda la historia. Este libro ilustrado se descarga gratuitamente y se ha divulgado bajo licencia Creative Commons en Parafernalia Ediciones Digitales en el 2015. Tiene más de 1,400 visitas. 
Encuentro №. 104, 53-80, 2016

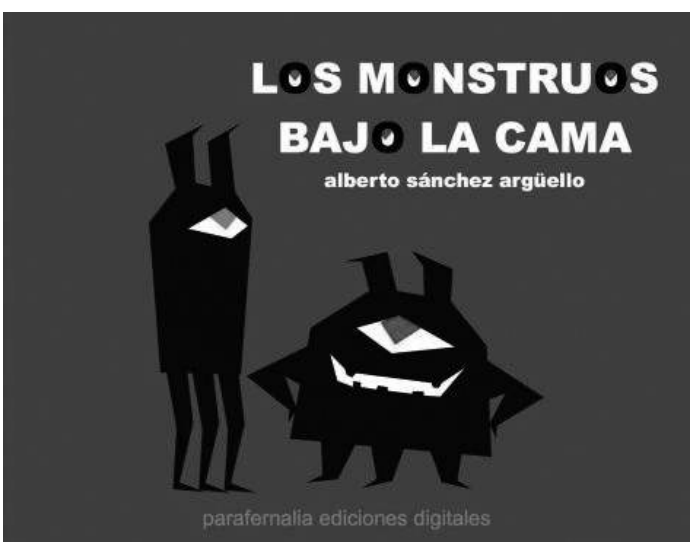

Fig. 38: Portada de 'Los monstruos bajo la cama'

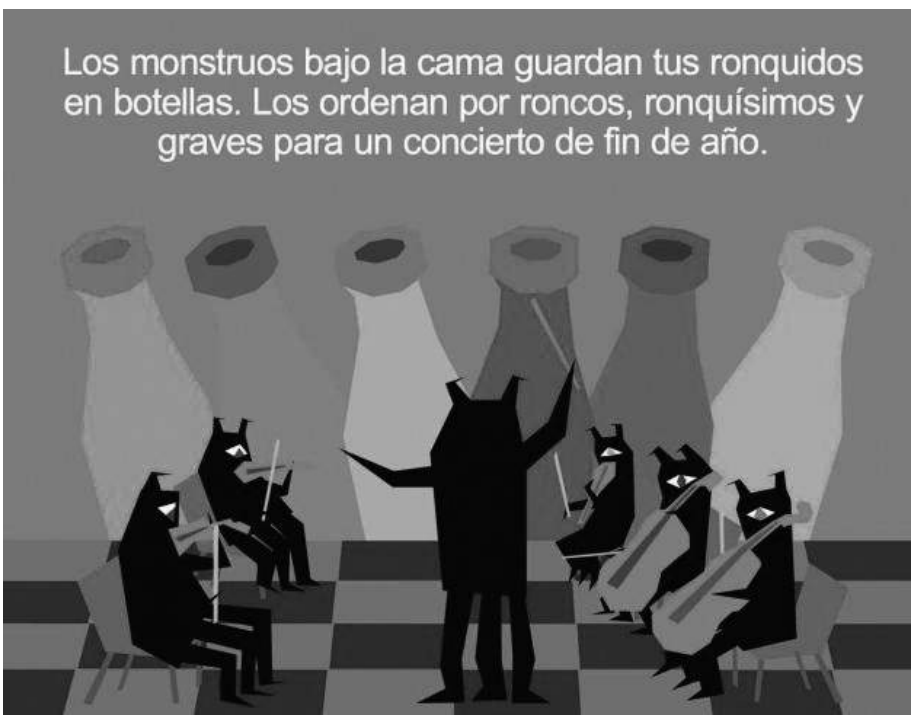

Fig. 39: Página 24. 'Los monstruos bajo la cama'

La función de la imagen es predominantemente narrativa. Al encontrarse en descarga gratuita, el Taller de Cartonería de la Faro Tláhuac de México (23 de abril de 2015) presentó una versión de 'Los monstruos bajo la cama' en formato de libro-arte-objeto, conmemorando el día del libro y se ha incluido como parte del curriculum de estudios de Lengua y Literatura Hispanoamericana (Spanish Language) de algunas secundarias privadas de Salt Lake City (Utah) en las que se leen e interpretan los microrrelatos.

\section{Conclusiones}

Existe una apuesta por el álbum ilustrado, pero desde las búsquedas personales de escritores e ilustradores interesados en este género. La mayoría de las y los ilustradores involucrados en el corpus estudiado son extranjeros, lo que sugiere que en Nicaragua 
se deben mejorar las capacidades de los ilustradores.

En el caso del ilustrador nicaragüense Lonnie Ruiz, se ve un crecimiento como ilustrador desde su primera obra, 'Un naufragio inesperado' (2007), hasta 'Elefante solitario' (2009). En el caso de 'Sapos' (2009), Ruiz ${ }^{22}$ comenta sobre su proceso creativo como escritor e ilustrador: "pero ahí fui un poquito más consciente de que el texto no necesitaba ser tan descriptivo de la imagen, más bien me aproveché de las cosas que ya habían dentro del personaje y la ilustración y decía cosas más básicas porque la imagen ya lo tenía.”.

'Mi amigo el dragón' es uno de los libros que apunta más a las características del álbum ilustrado. "Espero que esta conversación incluya también al lector o la lectora y los invite a descubrir las respuestas a los pequeños enigmas en cada lámina... y que todo esto resulte en el placer y el encanto de leer un álbum ilustrado”, comparte Wen Hsu Chen, ilustradora de esta obra.

Un álbum ilustrado persigue construir significado no sólo entre texto e ilustración abrazados, sino, más bien, entre autores y lectores. Se suma a esta reflexión Lonnie Ruiz: "Si el lector no lee las imágenes, va a ser muy difícil para él tener acceso a un conocimiento, contenidos, emociones y experiencias que están escondidos detrás de las imágenes y de las que él es co-autor, porque cuando los lectores te logran interpretar, también llegan a ser autores en esa relación y creo que eso es lo que pasa con los álbumes ilustrados."

\section{El futuro del álbum ilustrado en Nicaragua}

La meta es comenzar, a través de la crítica literaria enfocada en la literatura infantil y juvenil, a fomentar el consumo del álbum ilustrado como un producto cultural. Es importante dimensionar las implicaciones que tiene crear este género de libros. En la medida en la que los padres y madres (y adultos en general) comprendan la relevancia del álbum ilustrado como herramienta para el pensamiento crítico, más importancia se le otorgará a la literatura infantil.

En el marco de esto, el Colectivo de Ilustradores de Nicaragua es una asociación de reciente creación (2013) que busca fortalecer las habilidades de sus miembros a través del intercambio de experiencias y consolidar una proyección grupal con acciones colectivas.

Las motivaciones para la conformación de este grupo son el amor por la ilustración, por la literatura infantil y juvenil, y las ganas de hacer cosas en colectivo. Actualmente el grupo se está afianzando y está trabajando en un portafolio colectivo, con el fin de que más ilustradores nicaragüenses estén involucrados en la producción de libros infantiles en Nicaragua.

Parte de sus miembros son Alberto Sánchez y Lonnie Ruiz. Varios de sus miembros han ilustrado publicaciones de Libros para Niños y tienen como fin comprometerse en su formación para que Nicaragua pueda presentar una oferta competitiva en el campo de la ilustración, tanto a nivel nacional como internacional.

22 Lonnie Ruiz (1982). Diseñador e ilustrador. Docente universitario. www.lonnieruiz.com. Citado en este artículo según entrevista concedida en marzo 2015 para este trabajo de investigación 


\section{Referencias bibliográficas}

Bosch, E. (2007). Hacia una definición del álbum. Anuario de investigación en literatura infantil y juvenil, (5), 25-46.

Bosch, E. \& Durán, T. (2011). Una tipología de las guardas de los álbumes. Dept. didàctica de l'educació visual i plàstica Universitat de Barcelona. Anuario de investigación en literatura infantil y juvenil, (9), 09-21.

Santonja Ricart, X. (2012). Panorama histórico de la literatura infantil y juvenil nicaragüense desde los años 60 hasta la actualidad. Universitat Autònoma de Barcelona. Anuario de investigación en literatura infantil y juvenil, (10), 173-194.

Van der Linden, S. (2008). L'album, le texte et l'image. Le français aujourd'hui, (161), 51-58. DOI : 10.3917/lfa.161.0051

\section{Anexo 1. Lista de entrevistas}

> Ruiz Gómez, Lonnie Martín. Diseñador Gráfico, Docente Universitario e Ilustrador nicaragüense (marzo y junio de 2015)

> Sánchez Argüello, Alberto. Psicólogo, Escritor e Ilustrador nicaragüense. Coordinador del Colectivo de Ilustradores de Nicaragua (abril y junio de 2015)

> Tellería Picón, Gabriela. Coordinadora del Fondo Editorial ¡Libros para Niños! (abril de 2015)

> Hsu Chen, Wen. Ilustradora chino-costarricense (abril de 2015)

\section{Anexo 2. Lista de publicaciones infantiles y juveniles nicaragüenses}

Alberto Pocasangre. (2014). Donde nacen las sirenas. Nicaragua: Fondo Editorial Libros para Niños.

> Alberto Sánchez Argüello. (2015). Los monstruos bajo la cama. febrero 2015, de Parafernalia Ediciones Digitales. Sitio web: http://issuu.com/ albertosanchezarguello/docs/monstruos_bajo_la_cama

Alberto Sánchez Argüello; Mario Campos Cuadra. (2003). La casa del agua. Nicaragua: Fondo Editorial Libros para Niños.

Alberto Sánchez Argüello; Wen Hsu. (2014). Mi amigo el dragón. Nicaragua: Fondo Editorial Libros para Niños.

Alfredo Valessi. (2006). La leyenda de la mariposa. Nicaragua: Aldilá Editor.

ANÓNIMO (cuento de la tradición oral miskita). (2014). ¿Por qué nadan así los patos?. Nicaragua: Editorial Libros para Niños. 
Antoine Houdar de la Motte; José Constantino Sánchez Vanegas; Rafael Torromé. (2003). Un pleito. Nicaragua: Fondo Editorial Libros para Niños.

> Asociación de Educación y Comunicación 'La Cuculmeca'. (2014). Jugando se aprende mejor. Nicaragua: 'La Cuculmeca'.

Auxiliadora Mendoza; Carlos Manuel Téllez. (2005). El poeta y otros cuentos. Nicaragua: Fondo Editorial Libros para Niños.

> Axel Davis Montiel Montenegro [et al.].(2008). Mis pequeños amigos. Nicaragua: Distribuidora Cultural.

> Carlos Mejía Godoy; Nivio López Vigil. (2011). Pastorela Nicaragüense. Nicaragua: Fondo Editorial Libros para Niños.

> Carlos Perezalonso; César Castañeda. (2011). El duende del bosque de la memoria. Nicaragua: Fondo Editorial Libros para Niños.

> Carlos Rubio Torres; Sandra Lavandeira. (2011). Las mazorcas prodigiosas de Candelaria soledad. Nicaragua: Fondo Editorial Libros para Niños.

$>$ Clemente Guido. (2005). Papito contame un cuento. Nicaragua: Distribuidora Cultural.

> Christian Santos; Pablo Danilo Téllez Vado. (2008). Canto de un sueño. Nicaragua: Distribuidora Cultural.

$>$ Danny Yaoska Osorio; Alexa Midence. (2011). La noche de todos los gatos. Nicaragua: Fondo Editorial Libros para Niños.

> Debora Webster Robert; María López Vigil; Nivio lópez Vigil. (2013). Porqué hablan así los dantos. Nicaragua: Fondo Editorial Libros para Niños.

> Donald Taylor Álvarado; María López Vigil; Nivio López Vigil. (2014). Porqué son enemigas la tortuga y la culebra. Nicaragua: Fondo Editorial Libros para Niños.

$>$ Eduardo Estrada Montenegro (2007). Güegüense para niños. Nicaragua: Editorial Gorky.

D Ernesto Cardenal Martínez. (2007). Apalka. Nicaragua: Fondo Editorial Libros para Niños.

$>$ Ernesto Cardenal; Vicky Ramos. (2010). Epigramas. Nicaragua: Fondo Editorial Libros para Niños. 
> Fondo Editorial Instituto Nicaragüense de Cultura. (1998. )Nuestro Príncipe Balum Botán. Nicaragua: Fondo Editorial Instituto Nicaragüense de Cultura.

$>$ Fondo Editorial Libros para Niños. (2015). Yo quiero a mi escuela. Nicaragua: Fondo Editorial Libros para Niños.

$>$ Fondo Editorial Libros para Niños. (2015.)Mi abuelita me quiere. Nicaragua: Fondo Editorial Libros para Niños.

$>$ Gioconda Belli; Wolf Erlbruch. (2005). El taller de las mariposas. Nicaragua: ANAMA Ediciones Centroamericanas.

$>$ Guillermo Cortez Dominguez; Eduardo Orozco Porto. (2006). La desaparición de los dinosaurios. Nicaragua: Editora de Arte, S.A.

> Hilda María Baltodano Reyes. (2013). iJuguemos, pues! Léxico de los juegos y aficiones del nicaragüense. Nicaragua: Editorial PAVSA.

> Iouri Langlet. (2014). Café con leche. Nicaragua: EDISA.

Johana Camacho Chávez; Césaly Cortés. (2013) Para qué quiere el ratón mi diente. Nicaragua: Fondo Editorial Libros para Niños.

$>$ Jorge Bautista Lara. (2007). Lucas y la tortuguita. Nicaragua: Publicidad Arellano Vásquez S. A.

> José Alberto Vega Miranda. (2010). La hormiga valiente. Nicaraga: José Vega Miranda.

> José Dolores Marchena Hurtado. (2003). El compadre pobre: tío coyote y tío conejo. Nicaragua: José Dolores Marchena Hurtado.

> José Dolores Marchena Hurtado. (2003). El conejo que le pidió a Dios lo hiciera más grande. Nicaragua: José Dolores Marchena Hurtado.

$>$ José Dolores Marchena Hurtado. (2005). El tigre, el mono y el perro. Nicaragua: José Dolores Marchena Hurtado.

> José Dolores Marchena Hurtado. (2009). El tesoro de la montaña. Nicaragua: José Dolores Marchena.

> José Dolores Marchena Hurtado; Álvaro Rodríguez (Ilustrador). (2005). El cicimique y la princesa. Nicaragua: José Dolores Marchena Hurtado.

$>$ Juana Vargas Tejada. (2002). Cuentos para niños muy niños. Nicaragua: Juan Vargas Tejada. 
> Katia Cardenal; Álvaro Borrasé. (2011). La luna y yo. Nicaragua: Fondo Editorial Libros para Niños.

D Lonnie Martín Ruíz Gómez. (2009). Sapos. Nicaragua: Fondo Editorial Libros para Niños.

> Luis Felipe Ulloa Forero; Dixon Moya; Marianela Marín Rodríguez. (2009). El niño radio y otros cuentos. Nicaragua: Fondo Editorial Libros para Niños.

> Luis Garay. (2012). Mi delantal. Nicaragua: Fondo Editorial Libros para Niños.

$>$ Lula Mayorga; Sandra Lavandeira. (2014). Mi gato Mostacho. Nicaragua: Fondo Editorial Libros para Niños.

> María López Vigil, Nivio López Vigil. (2005). Los dientes de Joaquín. Nicaragua: Fondo Editorial Libros para Niños.

> María López Vigil; Nivio López Vigil. (2007). Historia del muy bandido, igualado, rebelde, astuto, pícaro y siempre bailador Güegüense. Nicaragua: Fondo Editorial Libros para Niños, 2007.

> María López Vigil; Nivio López Vigil. (2008). Cinco noches arrechas. Nicaragua: Fondo Editorial Libros para Niños.

> María López Vigil; Nivio López Vigil. (2009). Un güegüe me contó. Nicaragua:Fondo Editorial Libros para Niños.

> María López Vigil; Nivio López Vigil. (2010). La lechera y el carbonero. Nicaragua: Fondo Editorial Libros para Niños.

> María López Vigil; Nivio López Vigil. (2014). Baile del Tun: Drama Guerrero entre Varón Kiché y Varón Rabinal Llamado Rabinal Achí. Nicaragua: Fondo Editorial Libros para Niños.

> María Milagros Terán Saborío. (2010). Poemas de una niña. Nicaragua: Fondo Editorial Libros para Niños.

$>$ Mario Montenegro Brenes. (2006). El caballito de palo. Nicaragua: Fondo Editorial Libros para Niños.

> Mario Montenegro. (2008). Historia de dos sapos y Gonzalo el cocodrilo. Nicaragua: Fondo Editorial Libros para Niños.

> Mario Montenegro; Alberto Sánchez Argüello; Roberto Meneses; Luis Álvarez; Dijema Méndez; Elizabeth López; José Luis Zapata; Marta Sandoval; Laura García; William Grigsby; Esmeralda Ferrey; Wendy Salgado; César Castañeda; 
Liz García; Solangie Jeréz; Luis Hernández. (2012). Canciones, cuentos y colores. Nicaragua: Fondo Editorial Libros para Niños.

> Mario Montenegro; Lonnie Martín Ruíz Gutiérrez. (2014) Escalerita de arroz, e hilo, papelillo y bambú. Nicaragua: INISER.

> Martha Leonor González Ortega. (2008). Corinita la tortuga. Nicaragua: 400 Elefantes.

> Mary Bushey; María López Vigil; Nivio López Vigil. (2013). Porqué son así lossapos. Nicaragua: Fondo Editorial Libros para Niños.

> Ministerio de Salud. (2013). Cuento infantil 'me sobra y me falta': material educativo para la promoción de la guía alimentaria nicaragüense. Nicaragua: Ministerio de Salud.

> Mónica Massiel Meza González. (2015). Una luz en el poemario de una niña. Nicaragua: G.R. Meza Ocampo.

$>$ Nivio López Vigil. (2009). Popol vuh. Nicaragua: Fondo Editorial Libros para Niños.

$>$ Oscar Adán Corea Briones. (2009). Cantos del grillo. Nicaragua: Fondo Editorial Libros para Niños.

$>$ Ovidio Ortega Reyes; Celeste González Rivas. (2005). Ahuizotes. Nicaragua: Fondo Editorial Libros para Niños.

$>$ Ovidio Ortega Reyes; Celeste González Rivas. (2013). Mis sentidos 1. Nicaragua: Fondo Editorial Libros para Niños.

> Ovidio Ortega Reyes; Celeste González Rivas. (2013). Mis sentidos 2. Nicaragua: Fondo Editorial Libros para Niños.

> Paola Mercedes Marchena López. (2004). La conejita dulce zanahoria. Nicaragua: José Dolores Marchena Hurtado.

> Pedro Alfonso Morales Pérez. (2005). El duende y otros cuentos. Nicaragua: Distribuidora Cultural.

$>$ Pedro Alfonso Morales. (2013). Antología infantil nicaragüense. Nicaragua: Centro Nicaragüense de Escritores.

> Pedro Alfonso Morales. (2013). La sal del azul del pan. Nicaragua: Editarte.

$>$ Pierre Pierson. (2008). La tribu guanama y el alma del invierno. Nicaragua: Hispamer. 
> Pierre Pierson. (2011). Alas nuevas. Nicaragua: Editorial Mar Dulce.

> Pierre Pierson. (2011). El despistado Güis. Nicaragua: Editorial Mar Dulce.

> Pierre Pierson. (2013). Un lejano pueblo. Nicaragua: Editorial Mar Dulce.

> Pierre Pierson. (2014). El árbol de los símboles. Nicaragua: Editorial Mar Dulce.

> Pierre Pierson; Pablo Pino. (2014). El escudo mágico. Nicaragua: Editorial Mar Dulce.

> Raquel Martínez Kühl. (2007) Mis colibríes. Nicaragua: Editorial La Prensa.

> Ricardo Barreto Rojas; Samuel Barreto Argüello. (1998) Las mariposas no mueren. Nicaragua: Editorial Tercer Milenio.

> Richard Melvin Moncada. (2008). Nicavoy y pinta: las aventuras de Nicavoy el viajero. Nicaragua: Richard Melvin Moncada.

Dosario Aguilar. (2006). La niña Blanca y los pájaros sin pié. Nicaragua: Editorial Hispamer.

> Rubén Darío. (2009). Margarita. Nicaragua: Fondo Editorial Libros para Niños.

Rubén Darío. (2010) Del trópico. Nicaragua: Fondo Editorial Libros para Niños.

Salvador Cardenal Barquero. (2005). Montaña en flor. Nicaragua: Fondo Editorial Libros para Niños.

Salvador Cardenal Barquero. (2009). Elefante solitario. Nicaragua: Editorial Libros para Niños.

Sergio Ramírez Mercado. (2006). El perro invisible. Nicaragua: Fondo Editorial Libros para Niños.

Sergio Ramírez Mercado; Vicky Ramos. (2013). La jirafa embarazada. Nicaragua: Fondo Editorial Libros para Niños.

> Ulises Humberto Salazar Medrano; Lonnie Martín Ruíz Gómez Martín. (2007). Un naufragio inesperado. Nicaragua: Fondo Editorial Libros para Niños.

$>$ Zoa Damaris Meza Bermúdez. (2007). La piñata. Nicaragua: Fondo Editorial Libros para Niños. 